Supporting Information for

\title{
Perovskite Quantum Dots as Multifunctional Interlayers in Perovskite Solar Cells with Dopant-Free Organic Hole Transporting Layers
}

Fangwen Cheng, Ruiqin He, Siqing Nie, Chongjian Zhang, Jun Yin, Jing Li, Nanfeng Zheng, Binghui Wu*

State Key Laboratory for Physical Chemistry of Solid Surfaces, Collaborative Innovation Center of Chemistry for Energy Materials, National \& Local Joint Engineering Research Center of Preparation Technology of Nanomaterials, College of Chemistry and Chemical Engineering, Pen-Tung Sah Institute of Micro-Nano Science and Technology, Xiamen University, Xiamen 361005, China.
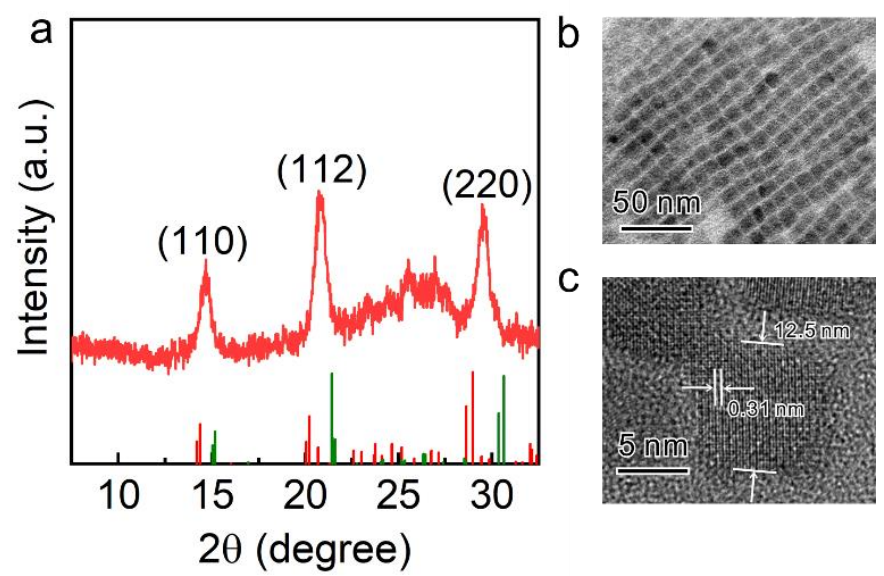

Figure S1. Structure characterization of perovskite QDs (taking $\mathrm{CsPbI}_{1.85} \mathrm{Br}_{1.15}$ as example). (a) XRD pattern (the standard XRD pattern of $\mathrm{CsPbI}_{3}$ was shown in red line and $\mathrm{CsPbBr}_{3}$ in green line), (b) low-magnification TEM image, and (c) high-resolution TEM image. The average crystalline size, estimated from Scherrer's formula by using FWHM of the (110) peak in XRD, was approximately $12.5 \mathrm{~nm}$, consistent with the dimension shown in the TEM images. And the d space value of (220) lattice fringes calculated from XRD and measured from TEM was both $0.31 \mathrm{~nm}$. 


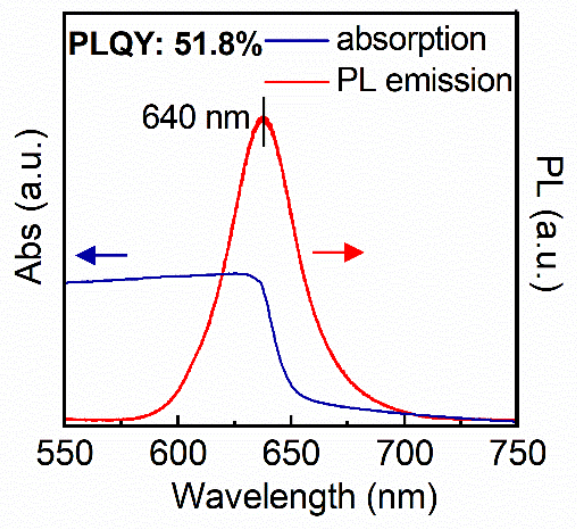

Figure S2. UV-vis absorption and PL emission spectra of perovskite QDs (take $\mathrm{CsPbI}_{1.85} \mathrm{Br}_{1.15}$ as example) in octane solution $(10 \mathrm{mg} / \mathrm{mL})$.
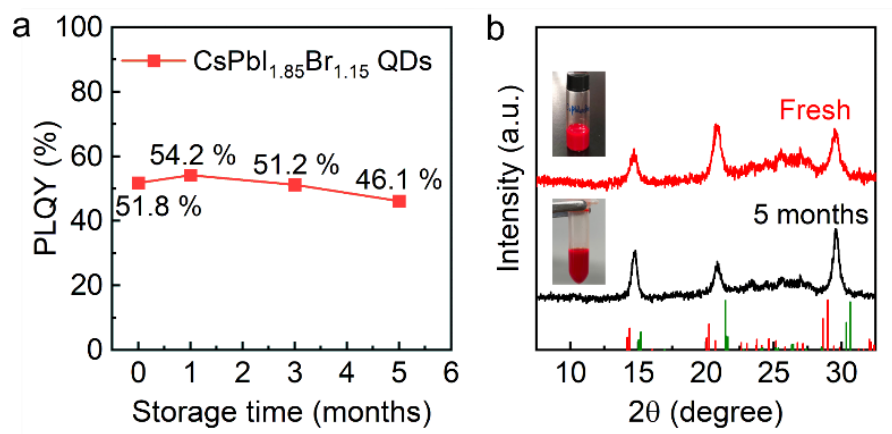

Figure S3. (a) Photoluminescence quantum yields (PLQY) of as-synthesized perovskite QDs (take $\mathrm{CsPbI}_{1.85} \mathrm{Br}_{1.15}$ as example) in octane solution $(10 \mathrm{mg} / \mathrm{mL})$. The solution of QDs was kept in a plastic tube and stored at room temperature in ambient air with $30-40 \%$ relative humidity. (b) XRD patterns of the corresponding QDs (standard red line: $\alpha-\mathrm{CsPbI}_{3}$, standard green line: $\alpha-\mathrm{CsPBr}_{3}$ ) Inset showed photos of fresh and stored QD/octane solution $(10 \mathrm{mg} / \mathrm{mL})$.
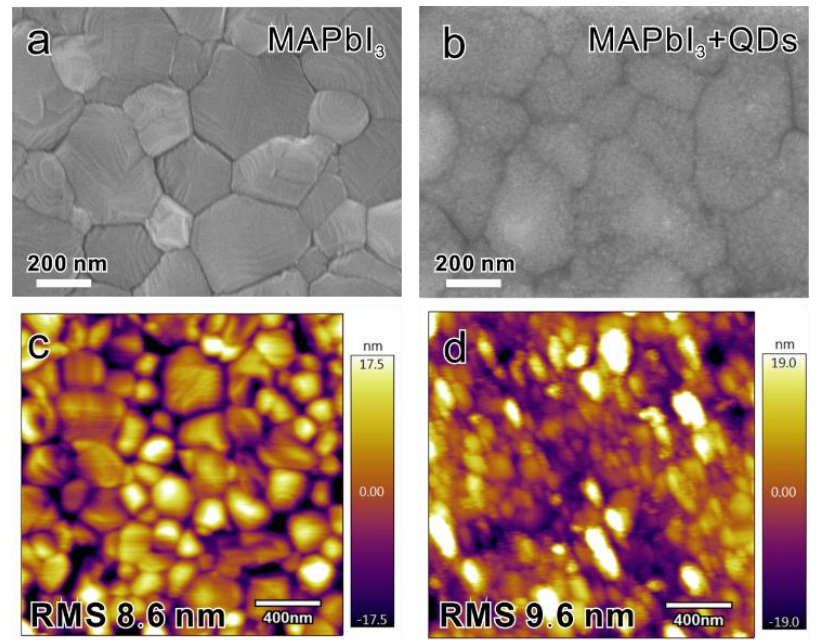

Figure S4. SEM and AFM images of $\mathrm{MAPbI}_{3}$ films (a,c) without QDs and (b,d) with perovskite QDs $\left(\mathrm{CsPbI}_{1.85} \mathrm{Br}_{1.15}\right)$ on the surface. 

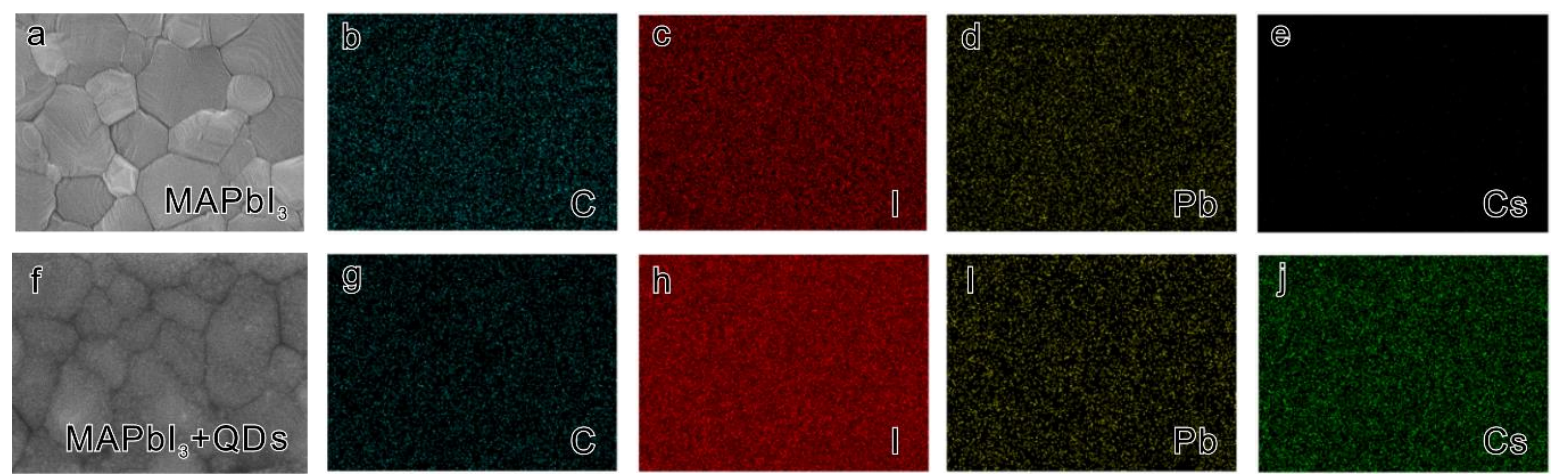

Figure S5. EDX measurement of $\mathrm{MAPbI}_{3}$ films (a-e) without perovskite QDs and (f-j) with perovskite $\mathrm{QDs}\left(\mathrm{CsPbI}_{1.85} \mathrm{Br}_{1.15}\right)$ on the surface.
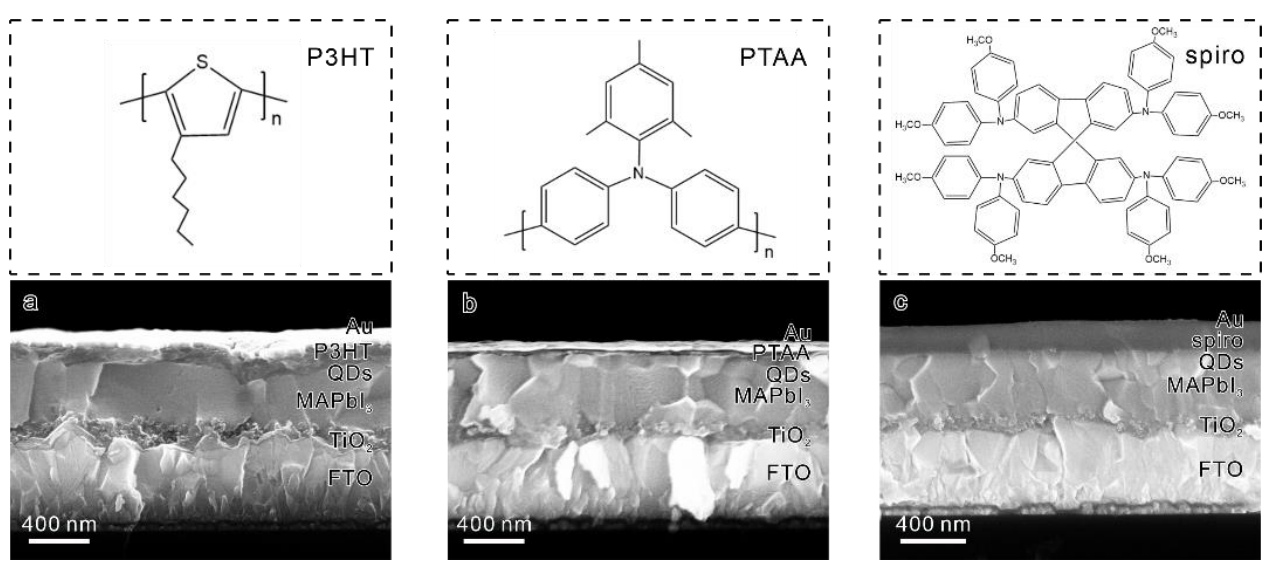

Figure S6. Cross-section SEM images of (a) P3HT-based PSC, (b) PTAA-based PSC and (c) spiro-based PSC. All PSCs herein were fabricated with QD interlayers and without any dopant in corresponding dopant-free o-HTMs.
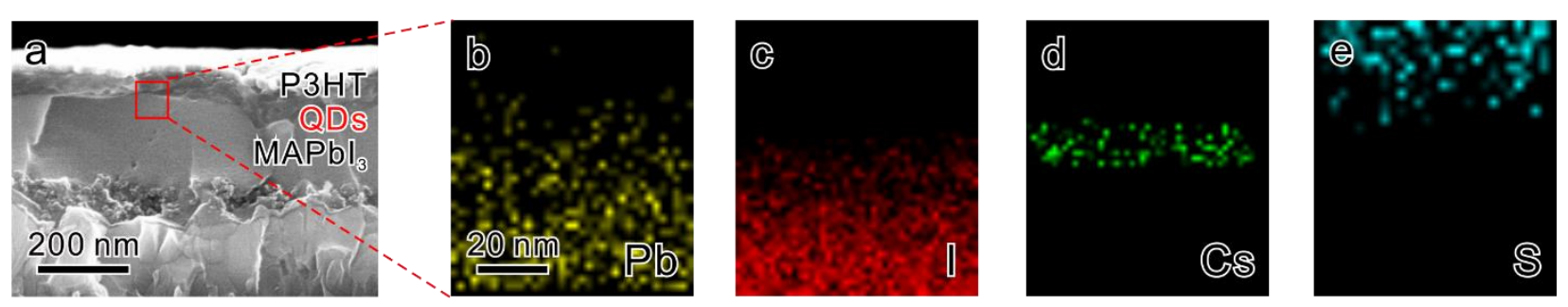

Figure S7. Cross-section SEM image and EDX mapping of a dopant-free P3HT-based PSCs device with QD interlayer. The Cs signal indicated the presence of QDs and S signal represented the existence of $\mathrm{P} 3 \mathrm{HT}$. 

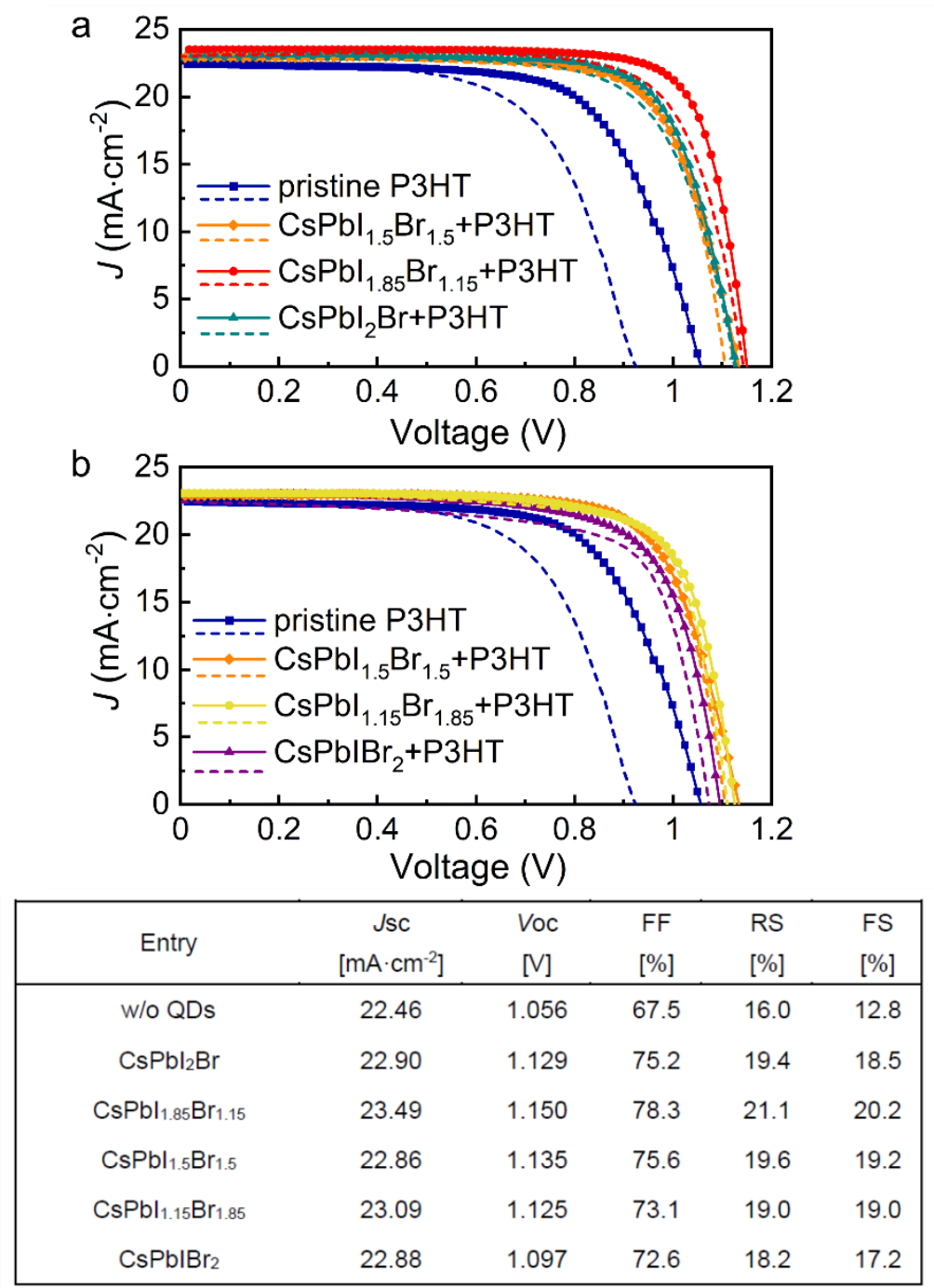

RS : reverse scan ; FS : forward scan

Figure S8. Comparison of PCE of dopant-free P3HT-based PSCs with $\mathrm{CsPbI}_{\mathrm{x}} \mathrm{Br}_{1-\mathrm{x}} \mathrm{QD}$ interlayers of different compositions. (a) $J-V$ scan of the devices with I-rich QD composition. (b) $J-V$ scan of the devices with Br-rich QD composition. The $\mathrm{CsPbI}_{1.85} \mathrm{Br}_{1.15}$ QDs endowed the best performance of PSCs and were mostly used in this work. 


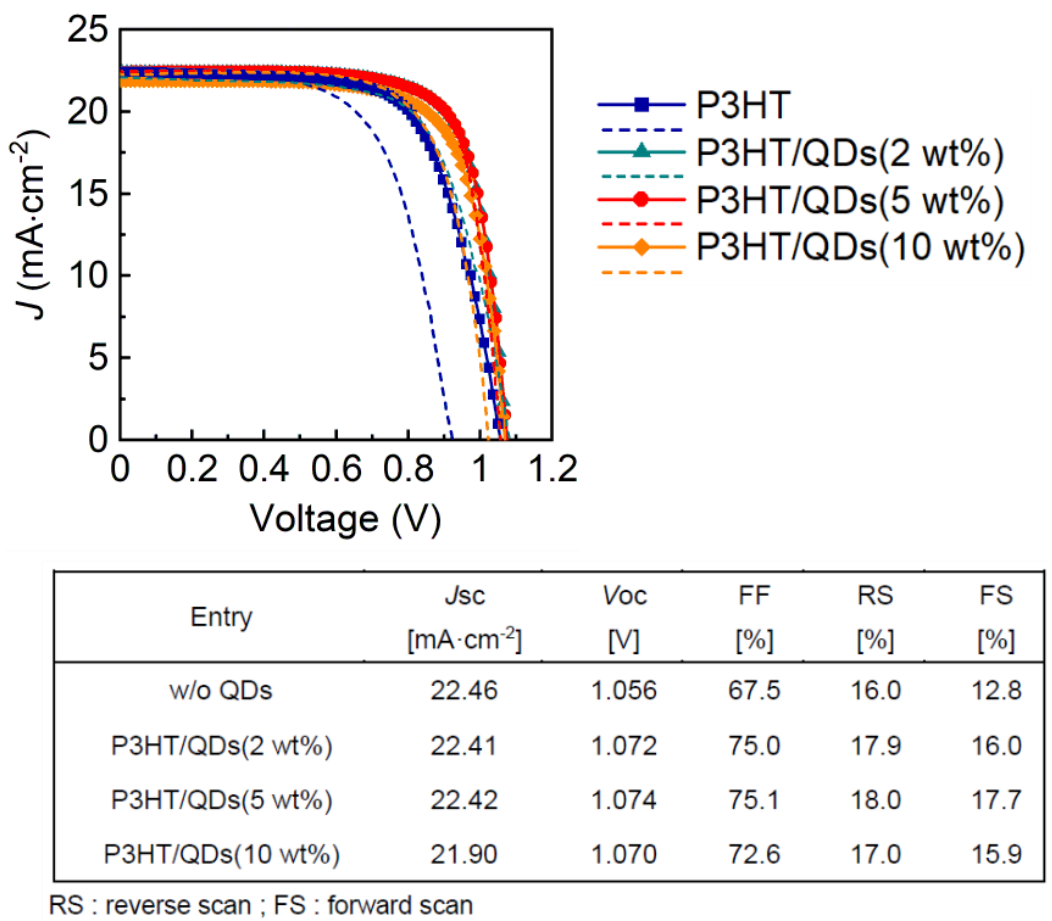

Figure S9. $J-V$ curves of PSCs with single layer of the QD-P3HT mixture (other than $\mathrm{QD} / \mathrm{P} 3 \mathrm{HT}$ bilayers) at different weight ratios.
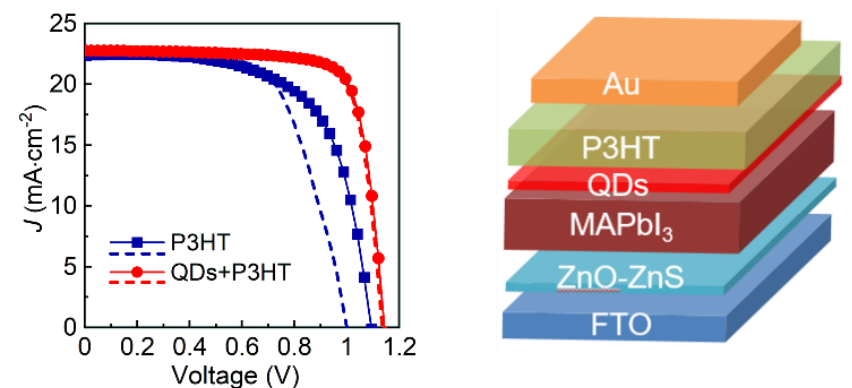

\begin{tabular}{|cccccc|}
\hline Entry & $\begin{array}{c}\text { JSC } \\
{\left[\mathrm{mA} \cdot \mathrm{cm}^{-2}\right]}\end{array}$ & $\begin{array}{c}\text { Voc } \\
{[\mathrm{V}]}\end{array}$ & $\begin{array}{c}\mathrm{FF} \\
{[\%]}\end{array}$ & $\begin{array}{c}\text { RS } \\
{[\%]}\end{array}$ & $\begin{array}{c}\text { FS } \\
{[\%]}\end{array}$ \\
\hline P3HT & 22.38 & 1.092 & 64.6 & 15.8 & 14.5 \\
QDS+P3HT & 22.78 & 1.143 & 77.3 & 20.1 & 20.0 \\
\hline
\end{tabular}

RS : reverse scan ; FS : forward scan

Figure S10. $J-V$ curves of dopant-free P3HT-based devices without or with QD interlayer using the device structure of $\mathrm{FTO} / \mathrm{ZnO}-\mathrm{ZnS} / \mathrm{MAPbI}_{3} / \mathrm{QDs} / \mathrm{P} 3 \mathrm{HT} / \mathrm{Au}$. The $\mathrm{ZnO}-\mathrm{ZnS}$ electron transporting layers and $\mathrm{MAPbI}_{3}$ were synthesized according to our recent papers. ${ }^{\mathrm{S} 1-2}$ 


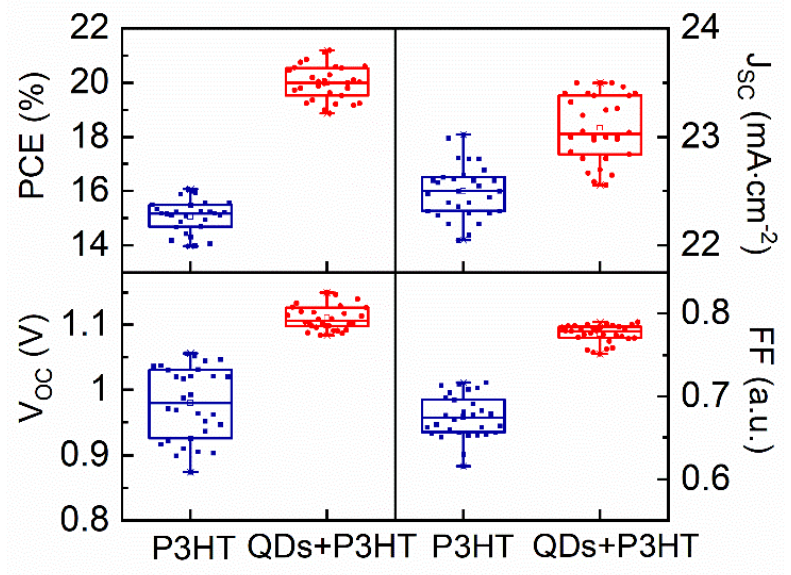

Figure S11. Accumulation of PCE, $J_{\mathrm{sc}}, V_{\mathrm{OC}}$ and FF for 30 dopant-free P3HT-based PSCs without and with QD interlayers.
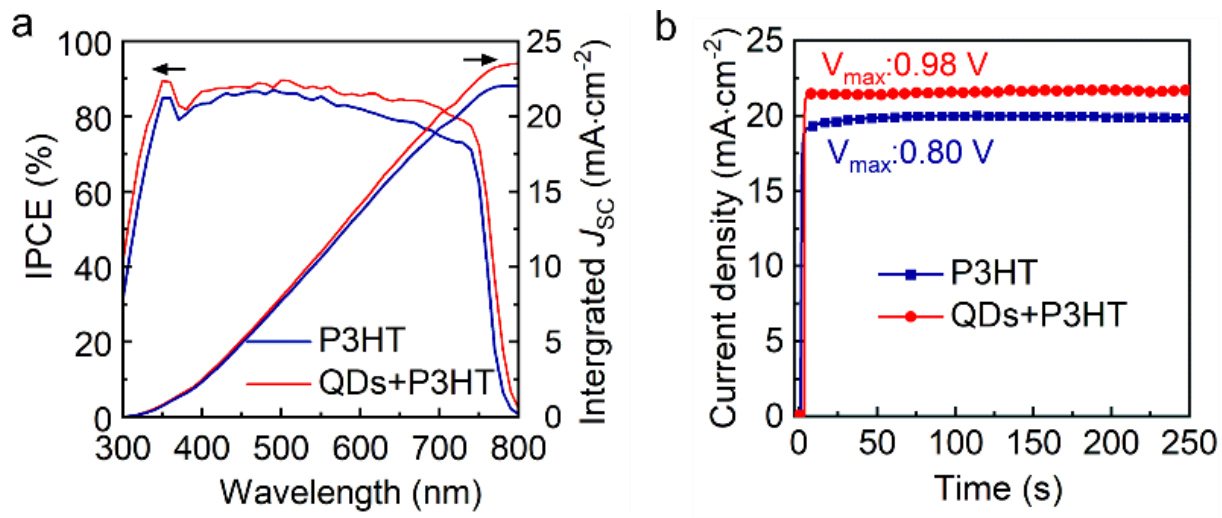

Figure S12. (a) IPCE curves and integrated $J_{\mathrm{SC}}$ for dopant-free P3HT-based PSCs without or with QD interlayer. (b) Stable photocurrent output at maximum power point for dopantfree P3HT-based PSCs without or with QD interlayer at corresponding voltages.

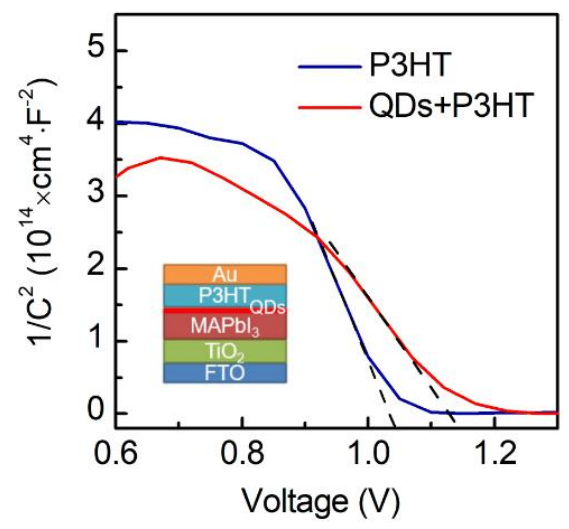

Figure S13. Mott-Schottky plots for dopant-free P3HT-based PSCs without or with QD interlayer. 


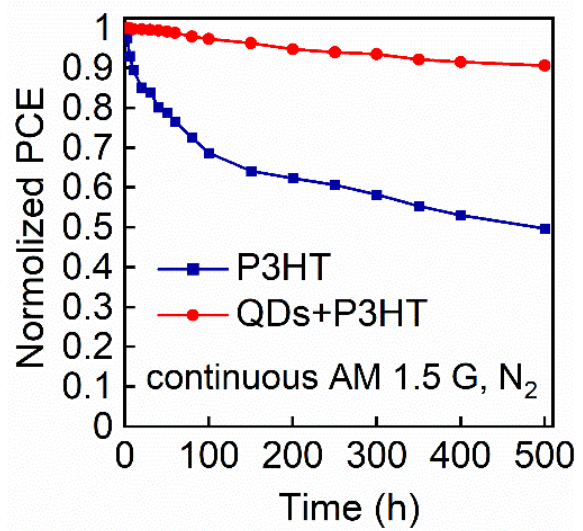

Figure S14. Normalized PCE stability of unencapsulated dopant-free P3HT-based PSCs without or with QD interlayer, under continuous AM 1.5G light soaking at room temperature in $\mathrm{N}_{2}$ atmosphere for 500 hours.

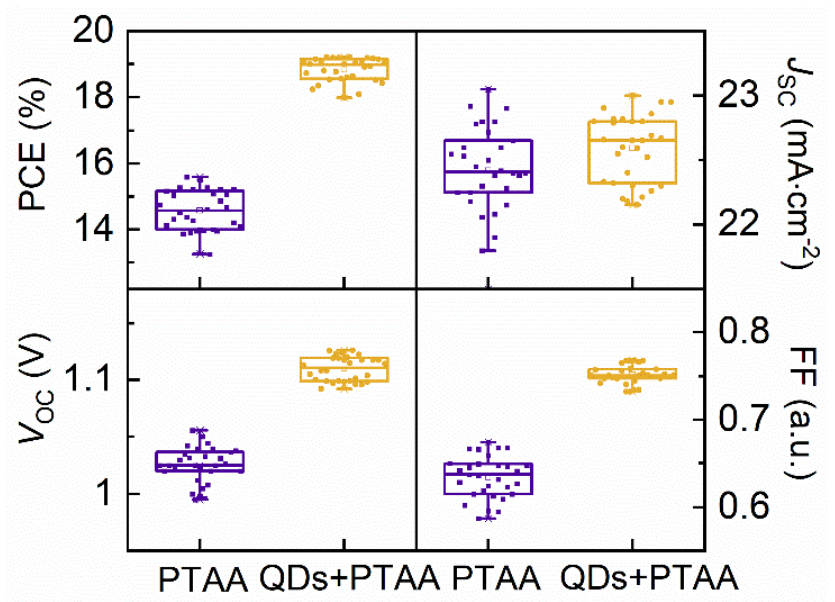

Figure S15. Accumulation of PCE and $V O C$ for 30 dopant-free PTAA-based PSCs without and with QD interlayers.

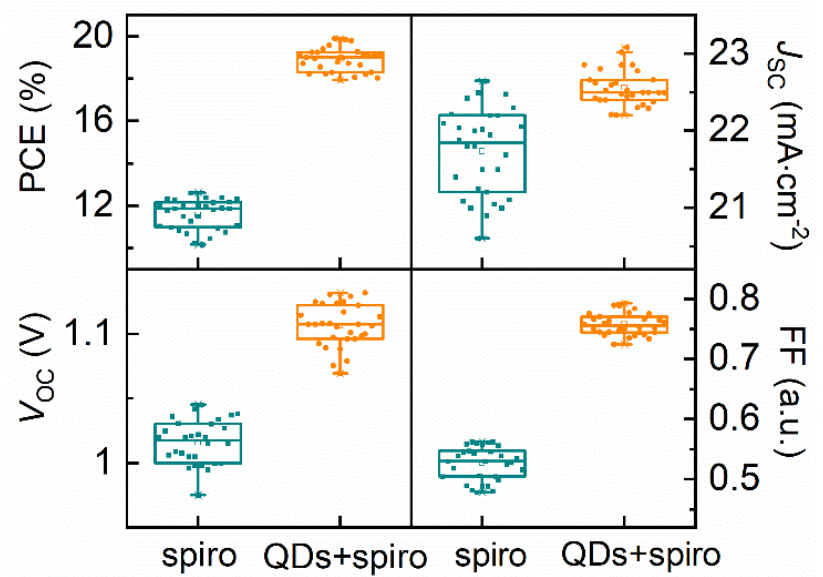

Figure S16. Accumulation of PCE and $V O C$ for 30 dopant-free spiro-based PSCs without and with QD interlayers. 

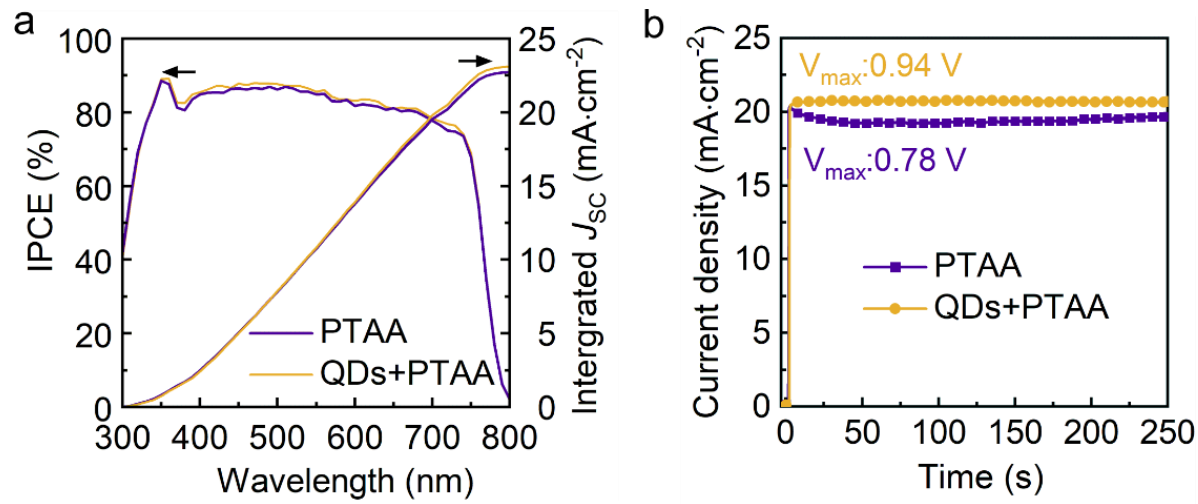

Figure S17. (a) IPCE curves and integrated $J_{\mathrm{SC}}$ for dopant-free PTAA-based PSCs without or with QD interlayer. (b) Stable photocurrent output at maximum power point for dopantfree PTAA-based PSCs without or with QD interlayer at corresponding voltages. The device with QD interlayer kept stable for $250 \mathrm{~s}$, while control device showed fluctuation.
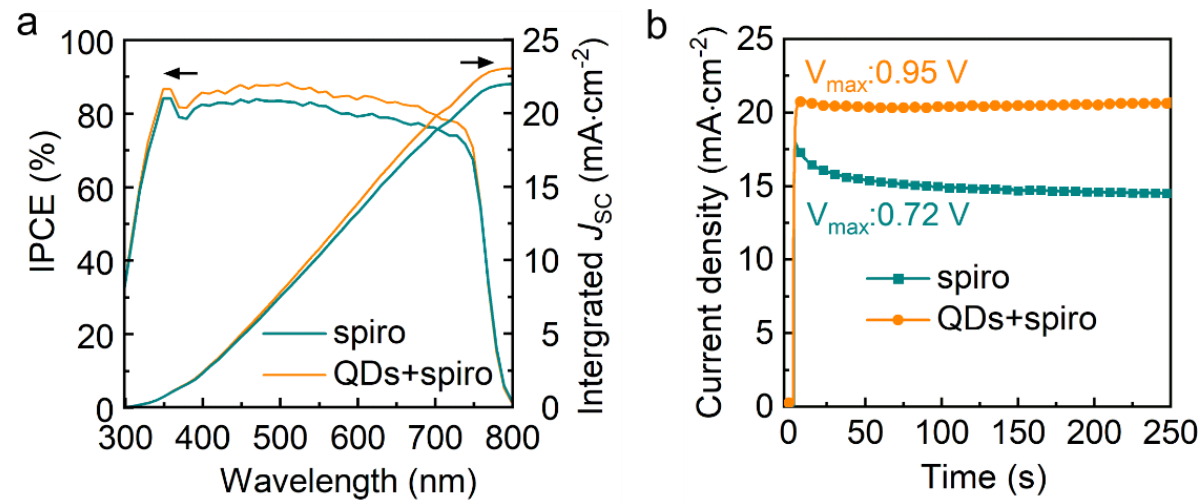

Figure S18. (a) IPCE curves and integrated $J_{\mathrm{SC}}$ for dopant-free spiro-based PSCs without or with QD interlayer. (b) Stable photocurrent output at maximum power point for dopantfree spiro-based PSCs without or with QD interlayer at corresponding voltages. The device with QDs kept stable output, while the photocurrent for control device showed rapid decay at the very first time.
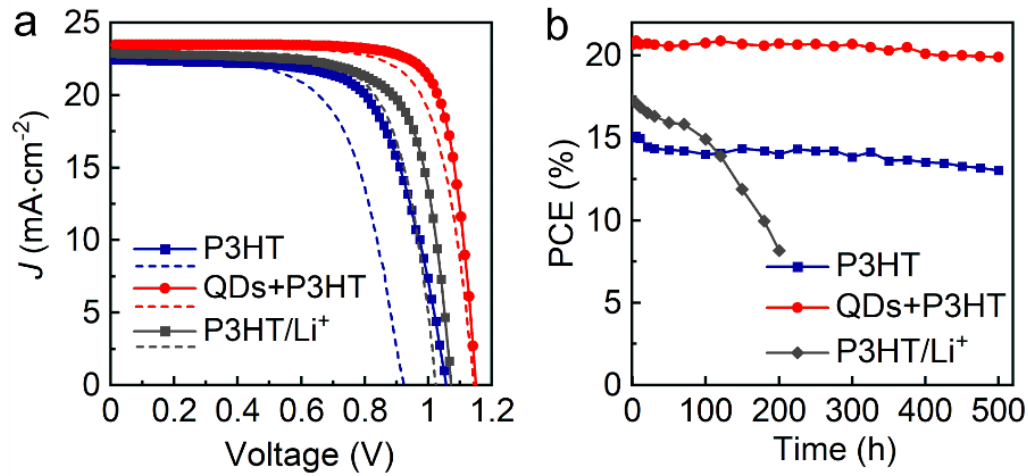

Figure S19. (a) $J-V$ curves (b) stabilities of unencapsulated PSCs with dopant-free P3HT single-layer, QDs and dopant-free P3HT bilayers, and lithium-doped P3HT single-layer. The PCE stability test was carried out under $60{ }^{\circ} \mathrm{C}$ in ambient air with relative humidity of 40\%-50\%. 

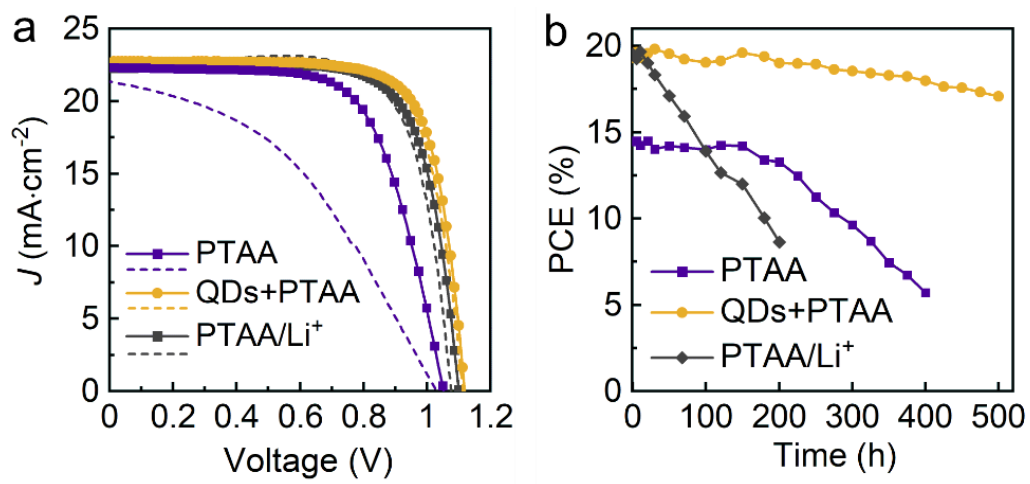

Figure S20. (a) $J-V$ curves (b) stabilities of unencapsulated PSCs with dopant-free PTAA single-layer, QDs and dopant-free PTAA bilayers, and lithium-doped PTAA single-layer. The PCE stability test was carried out under $60{ }^{\circ} \mathrm{C}$ in ambient air with relative humidity of 40\%-50\%.
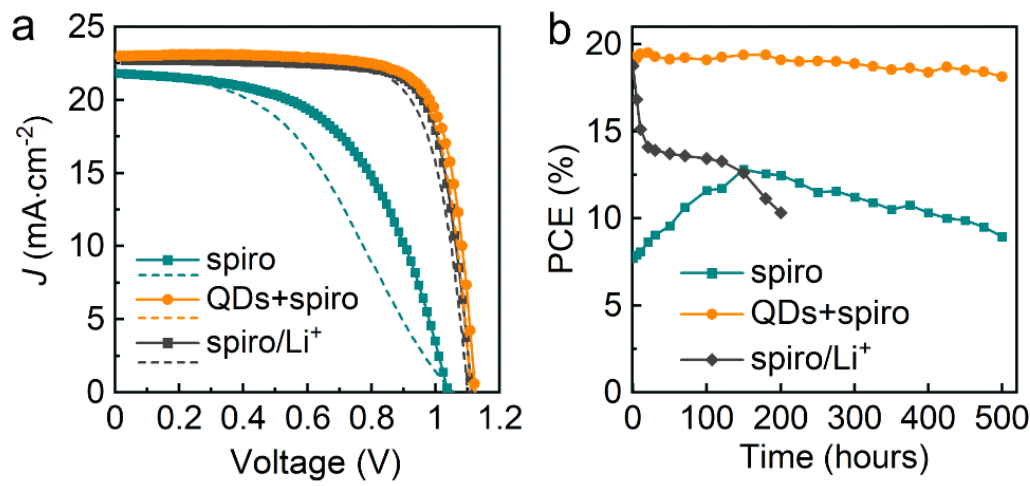

Figure S21. (a) $J-V$ curves (b) stabilities of unencapsulated PSCs with dopant-free spiro single-layer, QDs and dopant-free spiro bilayers, and lithium-doped spiro single-layer. The PCE stability test was carried out under $60^{\circ} \mathrm{C}$ in ambient air with relative humidity of $40 \%$ $50 \%$.
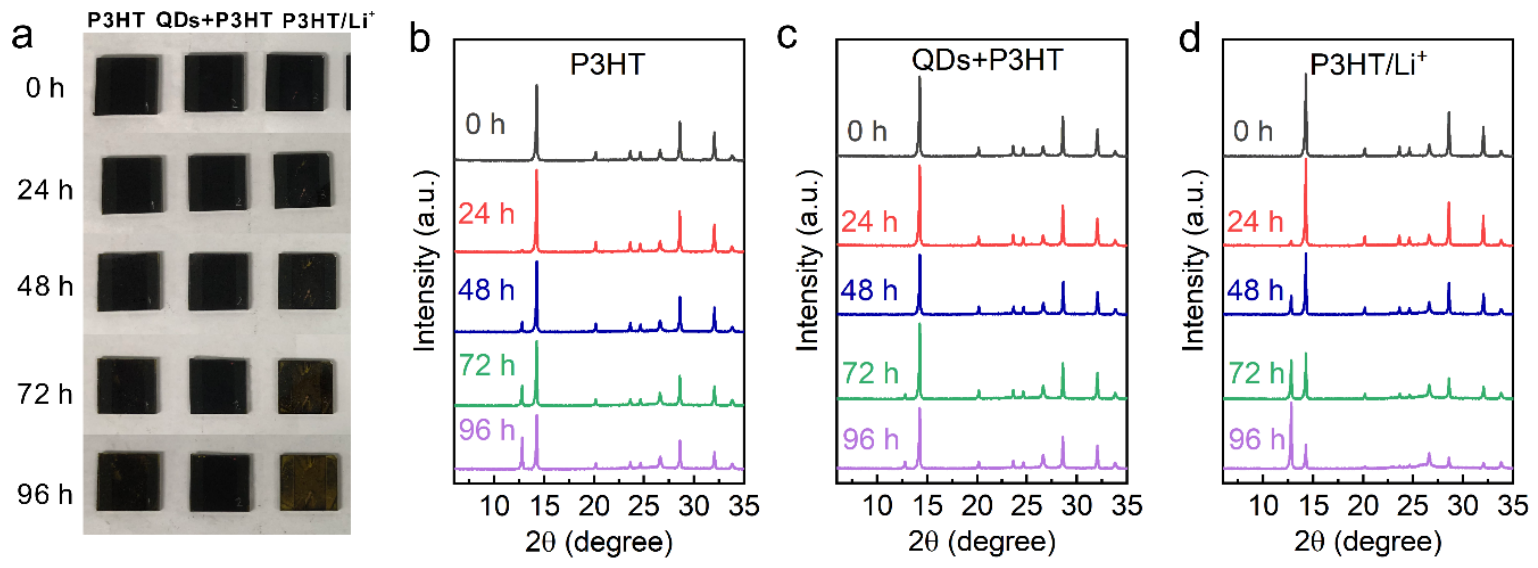

Figure S22. (a) Photos and (b-d) XRD patterns of $\mathrm{MAPbI}_{3}$ thin films covered with dopantfree P3HT single-layer, QDs and dopant-free P3HT bilayers, and lithium-doped P3HT single-layer. The aging test was under $85^{\circ} \mathrm{C}$ and $85 \%$ relative humidity. 

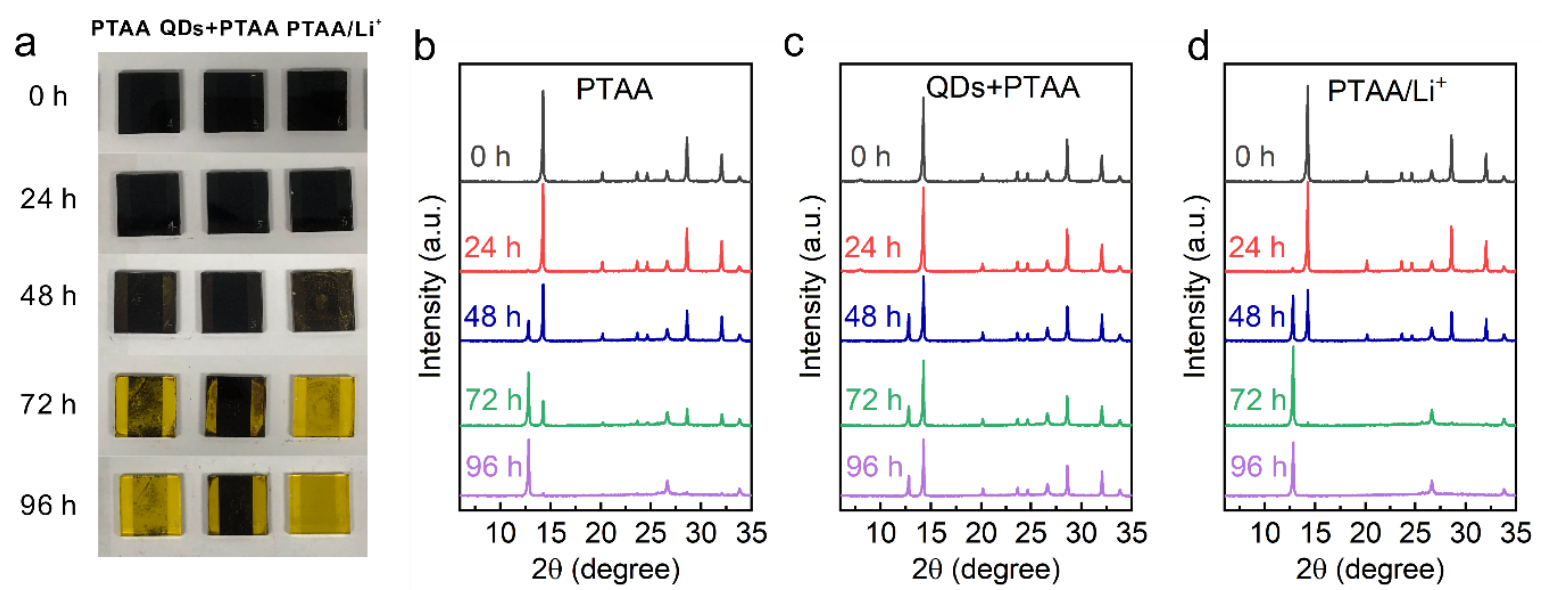

Figure S23. (a) Photos and (b-d) XRD patterns of $\mathrm{MAPbI}_{3}$ thin films covered with dopantfree PTAA single-layer, QDs and dopant-free PTAA bilayers, and lithium-doped PTAA single-layer. The aging test was under $85{ }^{\circ} \mathrm{C}$ and $85 \%$ relative humidity. To be noticed, although PTAA has been reported to keep perovskite stable in other works, unencapsulated perovskite thin films covered with PTAA was found to be relatively unstable compared to other two dopant-free HTMs (i.e., P3HT and spiro), probably due to slim thickness of PTAA film.
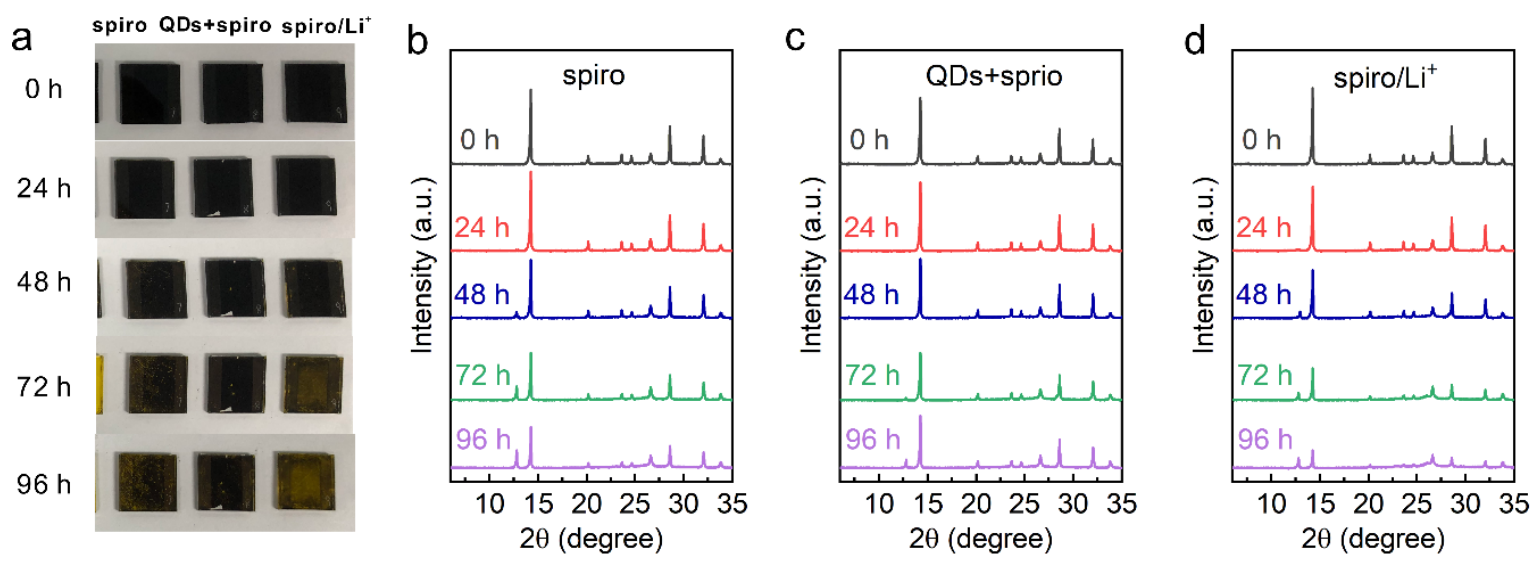

Figure S24. (a) Photos and (b-d) XRD patterns of $\mathrm{MAPbI}_{3}$ thin films covered with dopantfree spiro single-layer, QDs and dopant-free spiro bilayers, and lithium-doped spiro singlelayer. The aging test was under $85^{\circ} \mathrm{C}$ and $85 \%$ relative humidity. 


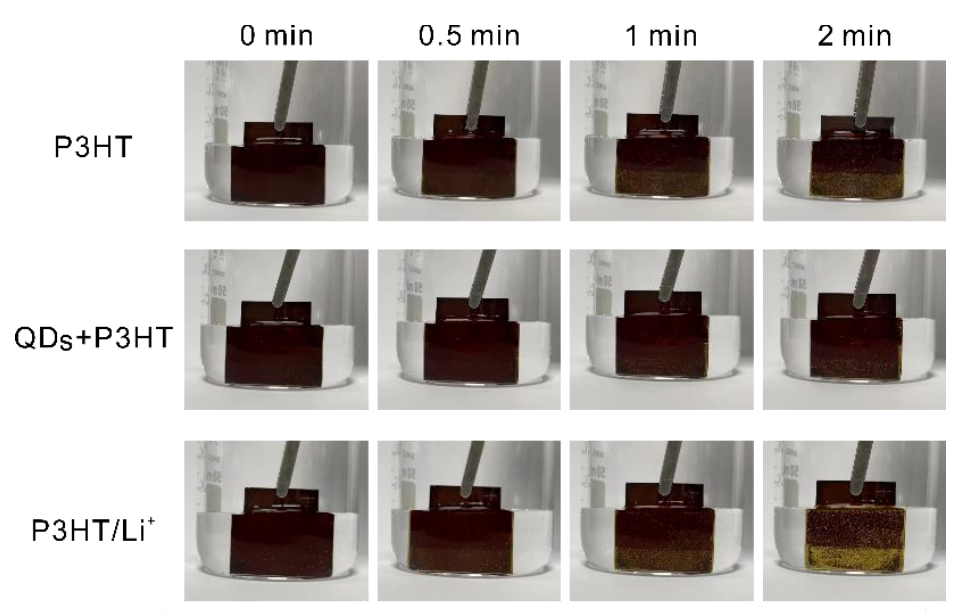

Figure S25. Photos of treatment progress and outcomes of $\mathrm{MAPbI}_{3}$ thin films in deionic water. The $\mathrm{MAPbI}_{3}$ thin films were pre-covered with dopant-free P3HT single-layer, QDs and dopant-free P3HT bilayers, and lithium-doped P3HT single-layer, respectively.

We have confirmed the stability of the as-used $\mathrm{CsPbI}_{1.85} \mathrm{Br}_{1.15}$ inorganic perovskite QDs, which can be stored without aggregation and phase transition for 5 months (Figure S3), and also the stability of devices fabricated with $\mathrm{CsPbI}_{1.85} \mathrm{Br}_{1.15}$ QDs and o-HTLs (Figure 1, S22-25). The novelty and importance of our work using QDs are obvious, compared to ion doping in o-HTLs. Our work unveiled the multiple functions of QD interlayers in dopant-free o-HTL-based PSCs, that are, passivation of perovskite surface, formation of cascade energy levels and regulation of undoped o-HTLs. We used QD interlayers to achieve high efficiency and stability of PSCs with different kinds of commercially available dopant-free o-HTLs. The mechanism we revealed in this work and the device performance we achieved with QDs and dopant-free o-HTLs pave a potential way for stable and practical PSCs in the future.
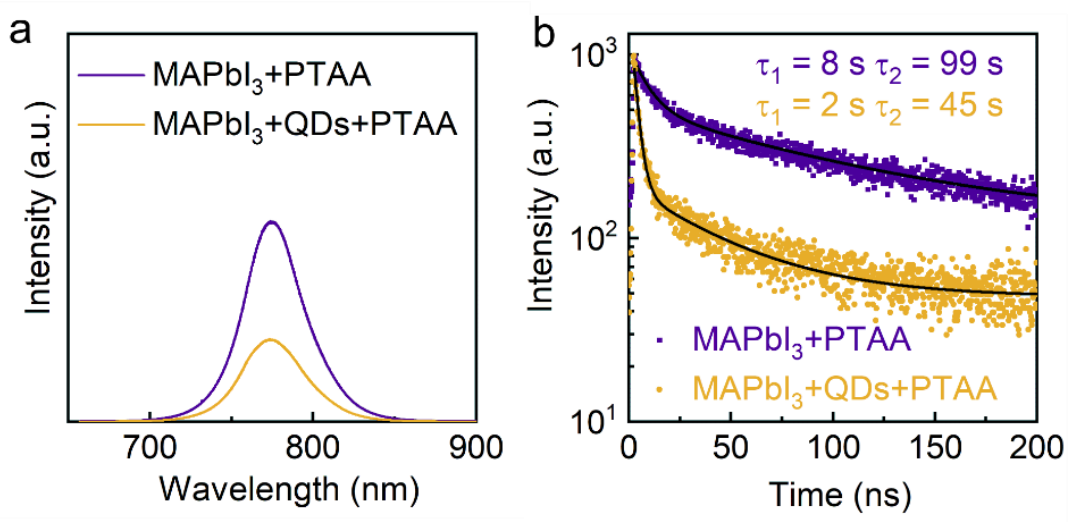

Figure S26. (a) Steady PL spectra and (b) time-resolved PL spectra of $\mathrm{MAPbI}_{3}$ films covered with dopant-free PTAA single-layer, or with QDs and dopant-free PTAA bilayers. 

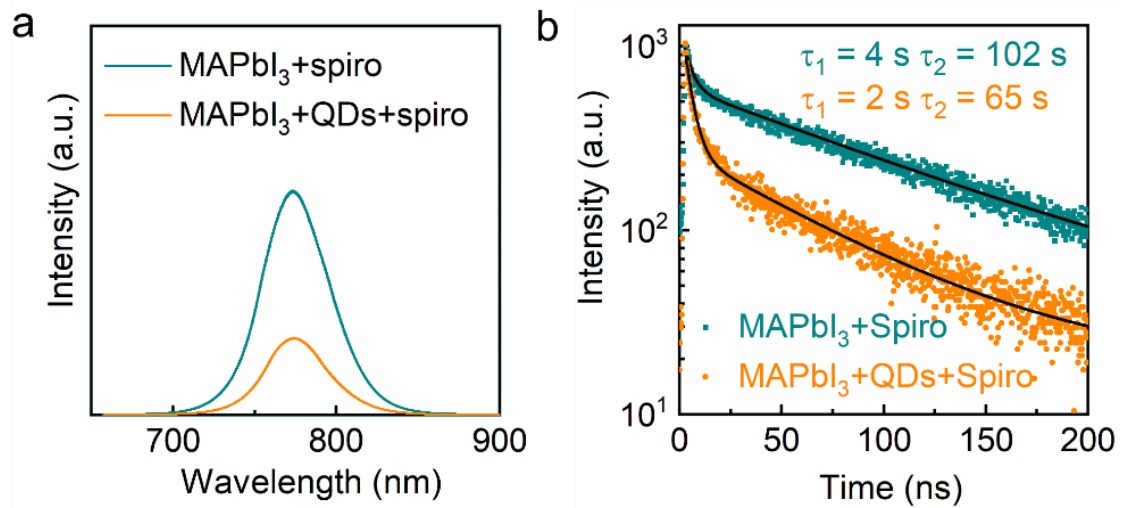

Figure S27. (a) Steady PL spectra and (b) time-resolved PL spectra of $\mathrm{MAPbI}_{3}$ films covered with dopant-free spiro single-layer, or with QDs and dopant-free spiro bilayers.

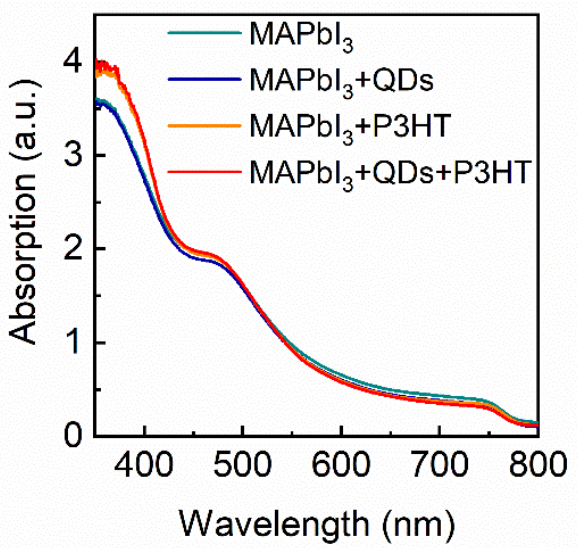

Figure S28. UV-vis absorption of $\mathrm{MAPbI}_{3}$ films covered with QD single-layer, dopantfree P3HT single-layer, or QDs and dopant-free spiro bilayers. All the absorption edge of those films was consistent at $775 \mathrm{~nm}$.
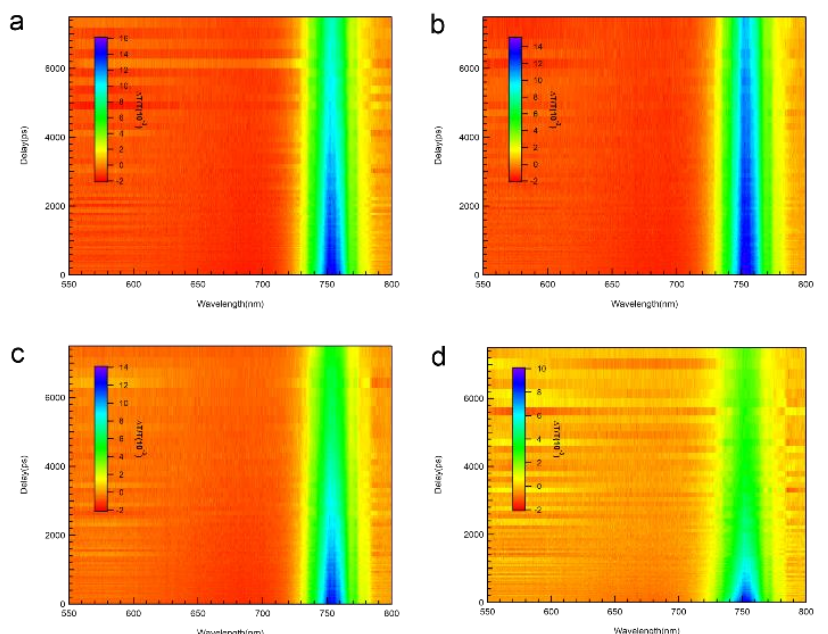

Figure S29. 2D pseudo-color graphs of transient absorption (TA) for (a) bare $\mathrm{MAPbI}_{3}$ film, (b) $\mathrm{MAPbI}_{3}$ film covered with QD single-layer, (c) $\mathrm{MAPbI}_{3}$ film covered with dopant-free P3HT single-layer, (d) $\mathrm{MAPbI}_{3}$ film covered with QD and dopant-free P3HT bilayers. No 
redshift of the transient bleach peak was observed, indicating a flat energy landscape and negligible tail states below the bandgap. The longer carrier decay time of QD-covered $\mathrm{MAPbI}_{3}$ than bare $\mathrm{MAPbI}_{3}$ (b vs. a) indicated the passivation effect of trap states using QDs. The faster carrier decay (c vs. d) meant the better hole extraction with QD interlayer between $\mathrm{MAPbI}_{3}$ and $\mathrm{P} 3 \mathrm{HT}$. To be noticed, all perovskite samples were spin-coated on FTO and the TA measurements were carried out at the back side of the film to exclude the influence from other layers.

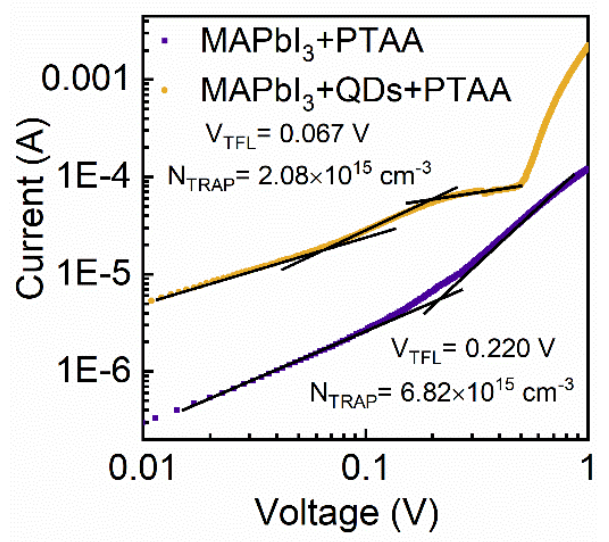

Figure S30. SCLC measurements of devices with the structure of $\mathrm{FTO} / \mathrm{NiO}$ X/perovskite/PTAA/Au without or with QD interlayer. $V_{\text {TFL }}$ was 0.220 and 0.067 $\mathrm{V}$ for the devices without and with QD interlayer, respectively. The defect density was calculated according to the equation $N_{\text {trap }}=2 \varepsilon_{\varepsilon} \varepsilon_{0} V_{\mathrm{TFL}} / \mathrm{e} \cdot \mathrm{L}^{2}$, where $\varepsilon$ and $\varepsilon_{0}$ are the dielectric constants of the perovskite and the vacuum permittivity, respectively, $\mathrm{L}$ is the thickness of the obtained perovskite film, and e is the elementary charge. The trap states density was calculated to be $6.82 \times 10^{15}$ and $2.08 \times 10^{15} \mathrm{~cm}^{-3}$ for the devices without and with QD interlayer, respectively.

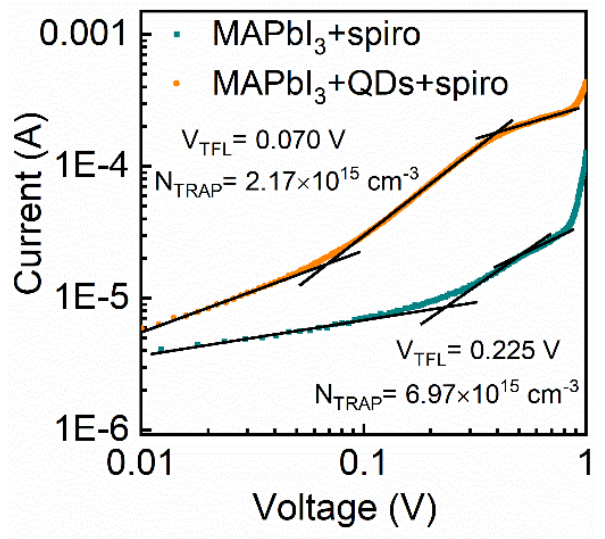

Figure S31. SCLC measurement of devices with structure of FTO/NiOX/perovskite/spiro/Au without or with QD interlayer. $V_{\text {TFL }}$ was 0.225 and 0.070 $\mathrm{V}$ for the devices without and with QD interlayer, respectively. The trap state density was calculated to be $6.97 \times 10^{15}$ and $2.17 \times 10^{15} \mathrm{~cm}^{-3}$ for the devices without and with QD interlayer, respectively. 


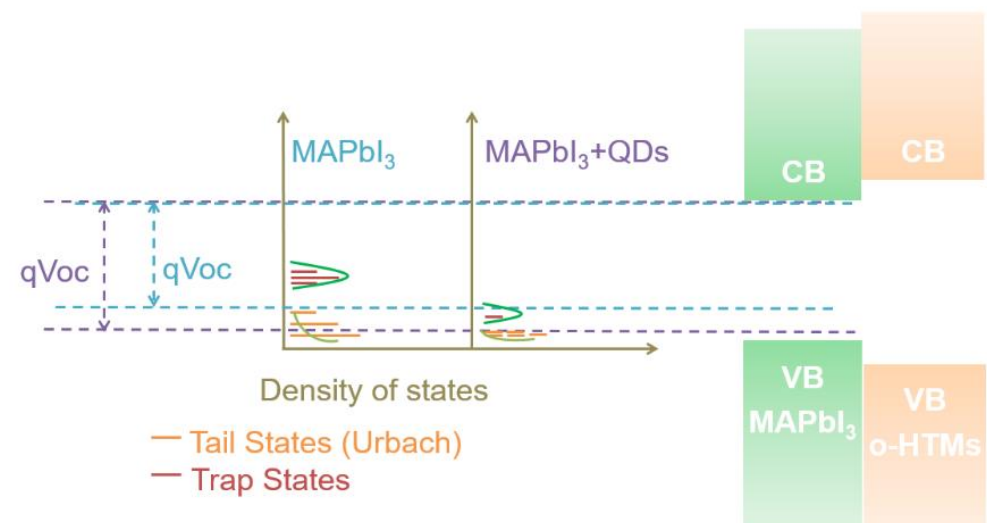

Figure S32. Schematic diagram of the tail states and trap states within the bandgap of perovskite layer, and their influence on the Voc of devices.
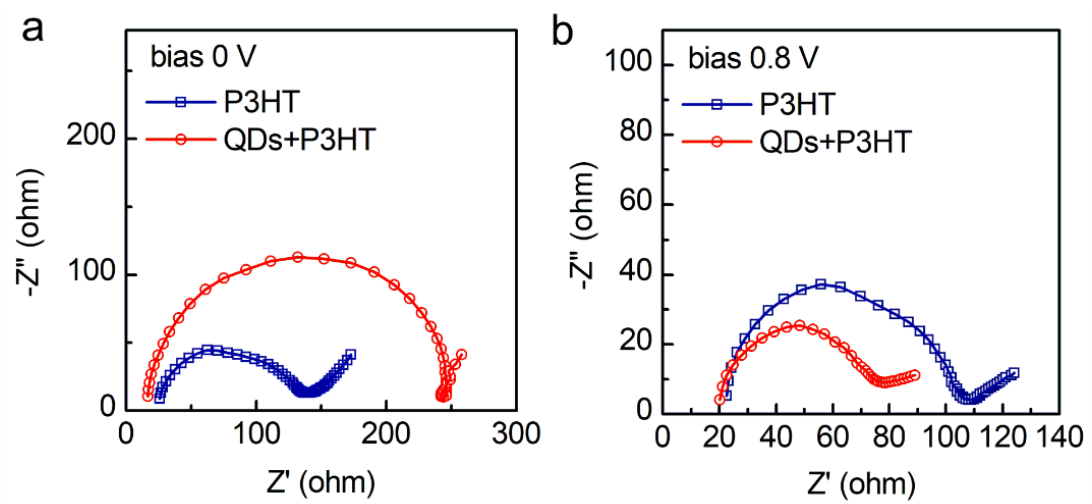

Figure S33. Electrical impedance spectroscopies (EIS) on whole dopant-free P3HT-based PSCs without or with QD interlayers at a bias of (a) $0 \mathrm{~V}$ or (b) $0.8 \mathrm{~V}$. The 0 -V impedance showed the charge recombination rate in the perovskite and at the interface, while the 0.8 $\mathrm{V}$ impedance referred to the charge transfer rate along the whole device.
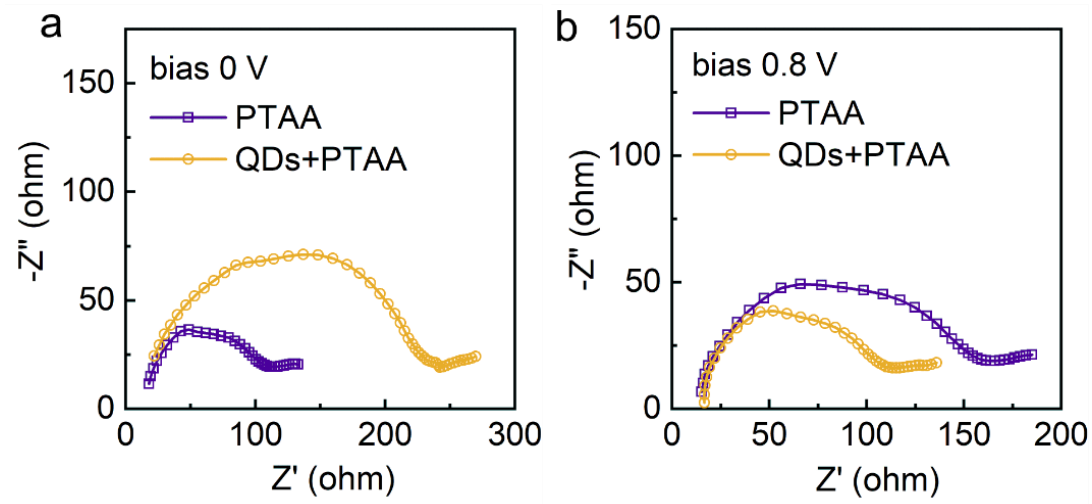

Figure S34. EIS on whole dopant-free PTAA-based PSCs without or with QD interlayer at a bias of (a) $0 \mathrm{~V}$ or (b) $0.8 \mathrm{~V}$. 

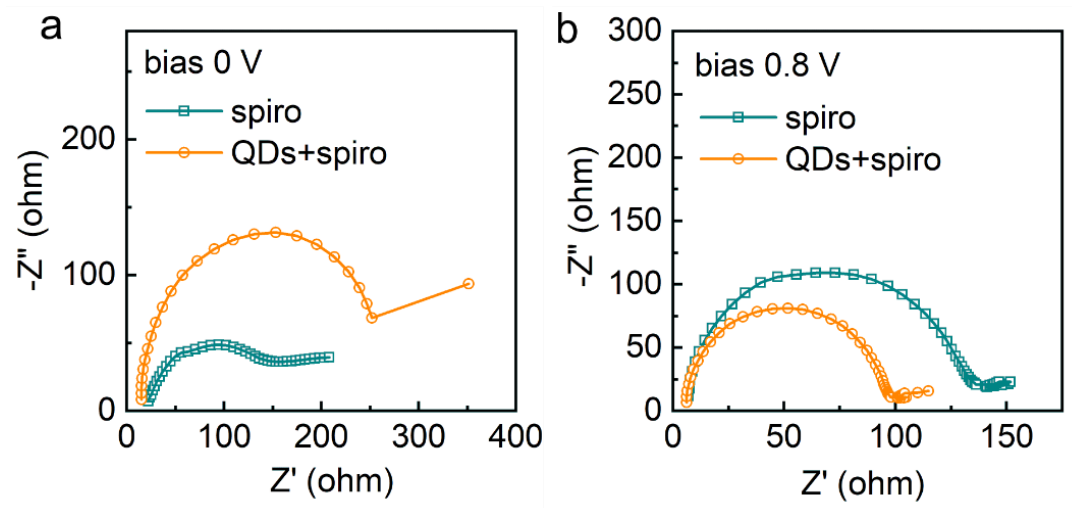

Figure S35. EIS on whole dopant-free spiro-based PSCs without or with QD interlayer at a bias of (a) $0 \mathrm{~V}$ or (b) $0.8 \mathrm{~V}$.

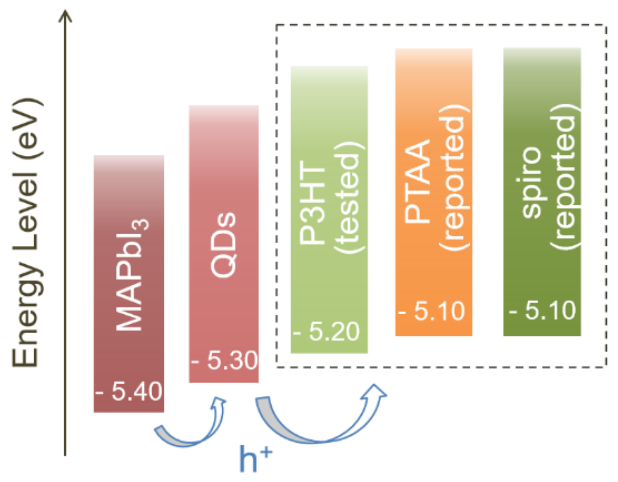

Figure S36. Schematic of valence band alignment with QD interlayer between $\mathrm{MAPbI}_{3}$ and each kind of dopant-free o-HTMs (P3HT, PTAA ${ }^{\mathrm{S} 3}$ and spiro $\left.{ }^{\mathrm{S} 4}\right)$. All cases formed an energy cascade, benefiting the hole transfer.

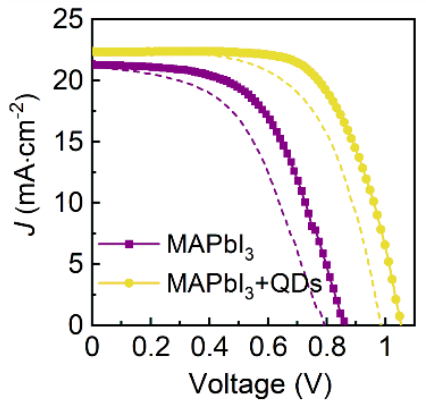

\begin{tabular}{|cccccc|}
\hline Entry & $\begin{array}{c}\text { Jsc } \\
{\left[\mathrm{mA} \cdot \mathrm{cm}^{-2}\right]}\end{array}$ & $\begin{array}{c}\text { Voc } \\
{[\mathrm{V}]}\end{array}$ & $\begin{array}{c}\text { FF } \\
{[\%]}\end{array}$ & $\begin{array}{c}\text { RS } \\
{[\%]}\end{array}$ & $\begin{array}{c}\text { FS } \\
{[\%]}\end{array}$ \\
\hline w/o HTLs & 21.30 & 0.863 & 55.6 & 10.2 & 8.8 \\
with QDs & 22.35 & 1.053 & 65.6 & 15.4 & 13.3 \\
\hline
\end{tabular}

Figure S37. $J-V$ curves of the device without any HTL (with structure of $\mathrm{FTO} / \mathrm{TiO}_{2} / \mathrm{MAPbI}_{3} / \mathrm{Au}$ ) and the device with QD interlayer between $\mathrm{MAPbI}_{3}$ and $\mathrm{Au}$ electrode $\left(\mathrm{FTO} / \mathrm{TiO}_{2} / \mathrm{MAPbI}_{3} / \mathrm{QDs} / \mathrm{Au}\right)$. The enhanced PCE indicated that graded valence band alignment formed by QDs on $\mathrm{MAPbI}_{3}$ film was beneficial to hole extraction in PSC device, consistent with the previously reported work. ${ }^{\mathrm{S} 5}$ 
We fabricated PSC devices without any HTLs and the efficiency comparison between those devices without or with QD layer on perovskite was shown. The improvement of efficiency with addition of QD layer on $\mathrm{MAPbI}_{3}$ was contributed to as-formed step fall energy cascade (Figure 3 and Figure S36) by QD interlayer on perovskite film, as proved by the increase in $V_{\mathrm{OC}}$. This trend was consistent with results from other previously reported work. ${ }^{\mathrm{S} 5}$ However, fill factor and $\mathrm{PCE}(15.4 \%)$ of $\mathrm{MAPbI}_{3} / \mathrm{QDs}$ device was not comparable with the device with HTLs $(21.1 \%$ for P3HT with QD interlayer or $17.6 \%$ for P3HT with dopants). This was partially due to that long-chain ligands on QD surface would prevent charge transfer. Figure S37 showed that the $\mathrm{MAPbI}_{3} / \mathrm{QDs}$ device without o-HTL had relatively large hysteresis. Overall, QD interlayer cannot totally replace HTL, despite that it can somehow improve device PCE without any HTLs.
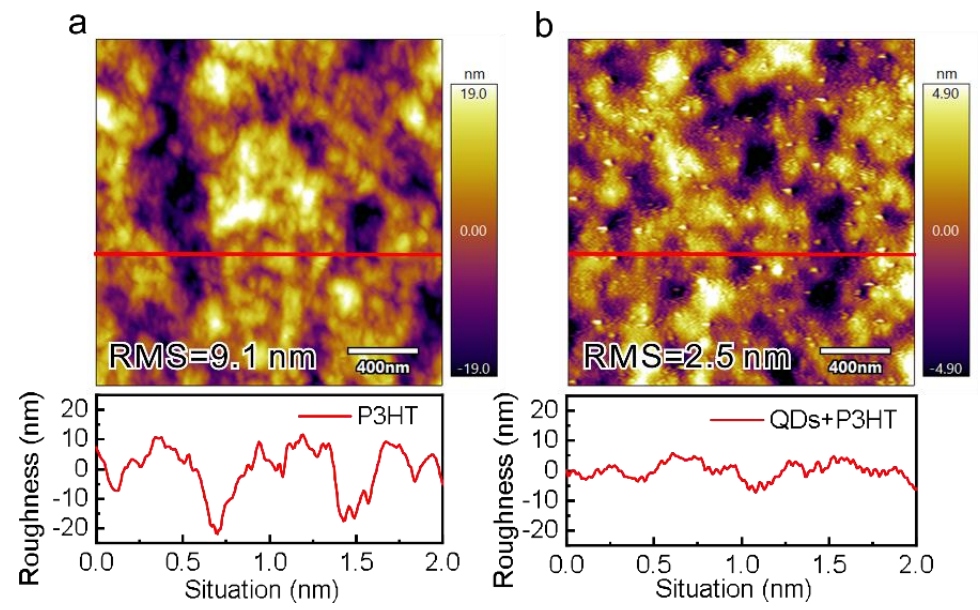

Figure S38. AFM image of $\mathrm{P} 3 \mathrm{HT}$ on $\mathrm{MAPbI}_{3}$ films (a) without or (b) with QD interlayer. P3HT on QD interlayer showed a smooth morphology, indicating that P3HT had a selfassembly behavior on QDs. And also, the pinhole density of P3HT layers can be decreased upon using QD interlayer, which can also be considered as a buffer layer.

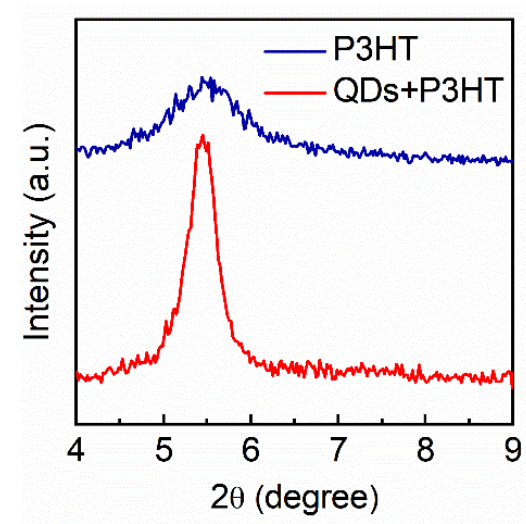

Figure S39. GIXRD patterns of $\mathrm{P} 3 \mathrm{HT}$ on $\mathrm{MAPbI}_{3}$ films without or with QD interlayer. The increased intensity of XRD peak at $5.5^{\circ}$ indicated improved crystallinity of P3HT on QD interlayer. 


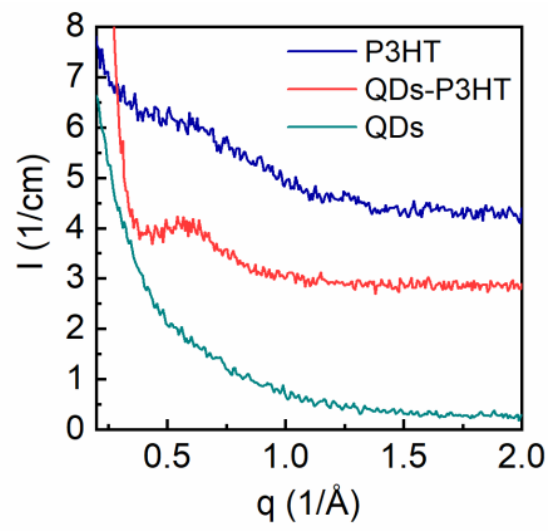

Figure S40. Small angle X-ray scattering (SAXS) patterns of $\mathrm{MAPbI}_{3}$ films covered with dopant-free P3HT single-layer, with QD and dopant-free P3HT bilayers, or with QD singlelayer. The bare QD film showed no peak, while the QDs-P3HT bilayers exhibited a peak at $0.58 \AA$, indicating that the 0.58 - $\AA$ peak was not due to the scattering of QD layer.
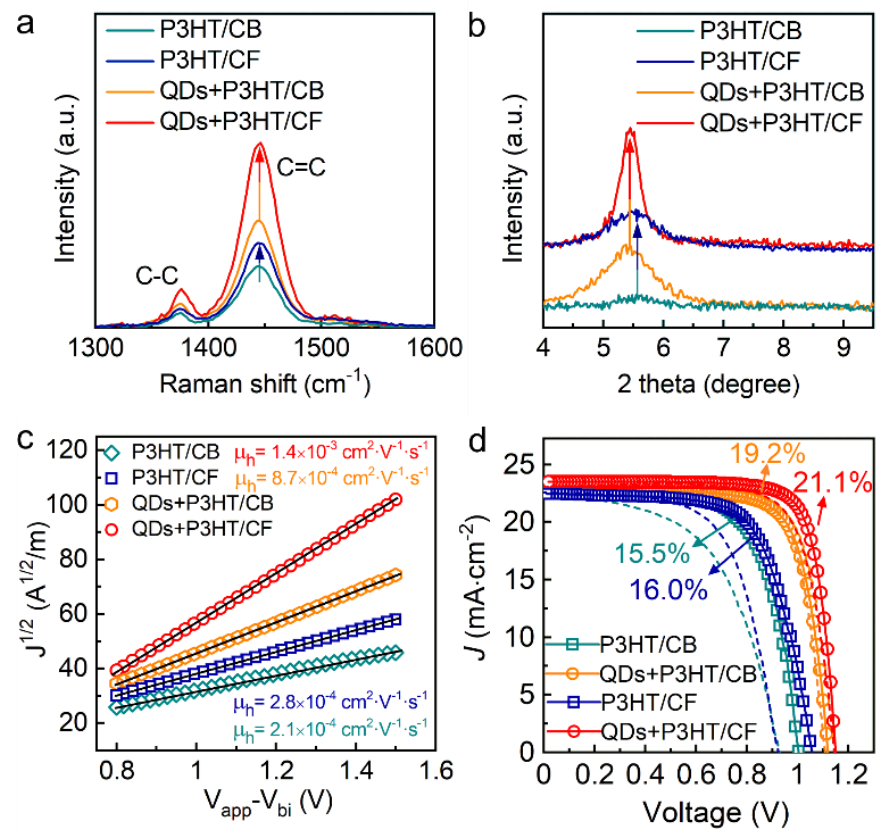

Figure S41. (a) Raman spectra and (b) GIXRD patterns of P3HT deposited from chlorobenzene (CB) and chloroform (CF) on bare $\mathrm{MAPbI}_{3}$, and $\mathrm{MAPbI}_{3}$ with QD layer. (c) Hole mobilities of P3HT films from CB or CF without or with QD layer. (d) $J-V$ curves of devices fabricated with $\mathrm{P} 3 \mathrm{HT}$ from $\mathrm{CB}$ or $\mathrm{CF}$ without or with QD layer.

As shown in the above Raman spectra (Figure S41a), the intrinsic signals for P3HT were enhanced when $\mathrm{CF}$ was used as solvent for P3HT deposition, compared to the case with $\mathrm{CB}$, indicating a better regularity resulting from solvent effect. GIXRD patterns (Figure S41b) showed that CF-involved P3HT was more crystalline than the CB-involved one, consistent with the Raman results. To be noticed, QD interlayer had regulation effect on P3HT no matter which solvent of P3HT was used. Due to structure-property relationship, regulation of polymers' structure influenced their semiconductive properties including the 
charge mobility, as demonstrated in Figure S41c. As a result of P3HT regulation improvement, devices fabricated with $\mathrm{P} 3 \mathrm{HT} / \mathrm{CF}$ was higher than the one with $\mathrm{P} 3 \mathrm{HT} / \mathrm{CB}$ (Figure S41d). Overall, optimized device PCE was achieved to $21.1 \%$ with combination of QD interlayer and CF solvent.
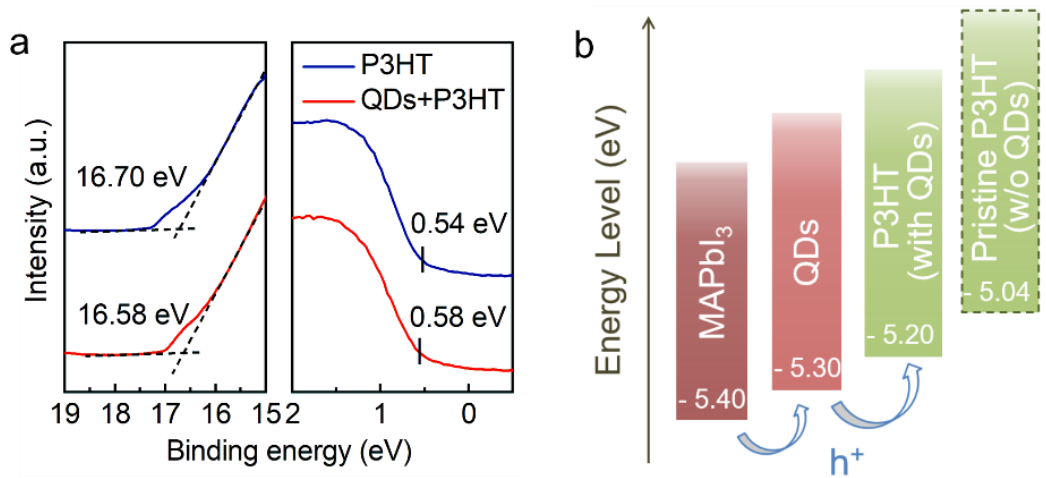

Figure S42. (a) UPS spectra of $\mathrm{P} 3 \mathrm{HT}$ on $\mathrm{MAPbI}_{3}$ film (blue) without or (red) with QD interlayer. (b) Schematic of energy band alignment in this work.

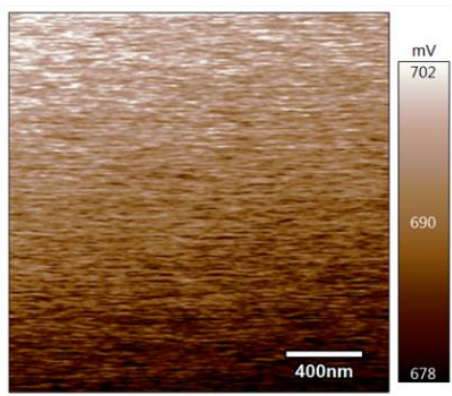

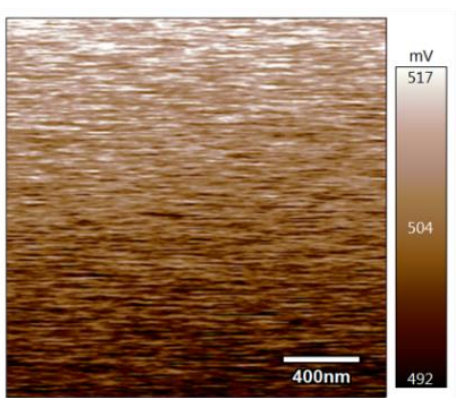

Figure S43. KPFM images of $\mathrm{P} 3 \mathrm{HT}$ on $\mathrm{MAPbI}_{3}$ film (a) without or (b) with QD interlayer. The latter showed a lower Fermi level.

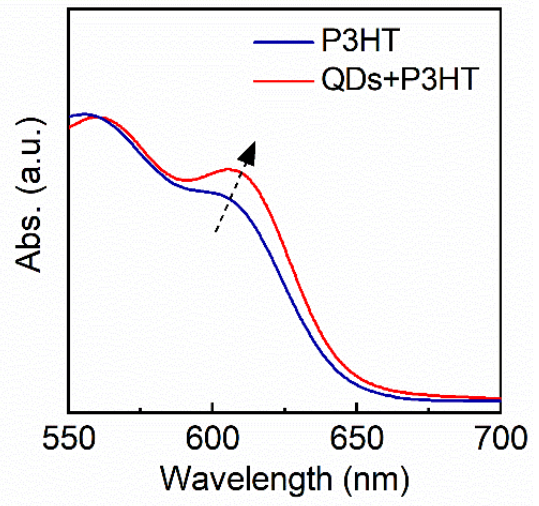

Figure S44. UV-vis absorption of films with the structure of FTO/P3HT or FTO/QDs/P3HT. An increase of peak intensity at $\lambda=605 \mathrm{~nm}$ indicated the regularity improvement of P3HT deposited on QD layer. 

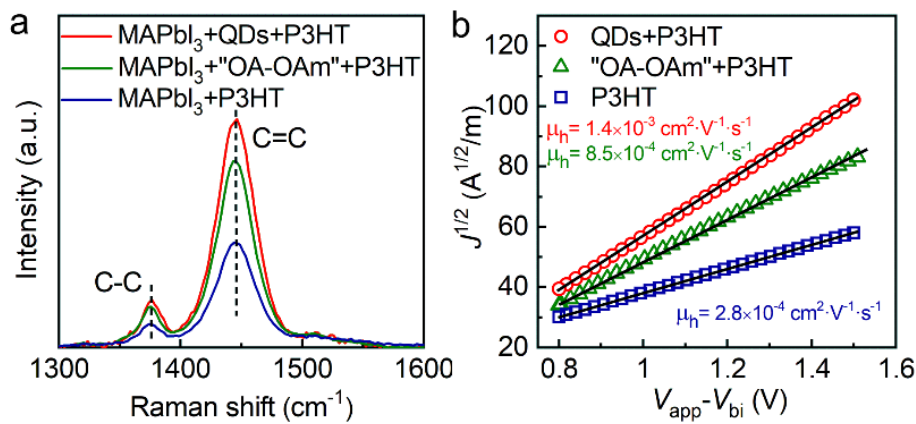

Figure S45. (a) Raman spectra of $\mathrm{P} 3 \mathrm{HT}$ on bare $\mathrm{MAPbI}_{3}$ and $\mathrm{MAPbI}_{3}$ with "OA-OAm" washed from QDs, and the one with QD interlayer and (b) hole mobilities of P3HT on the corresponding substrates.

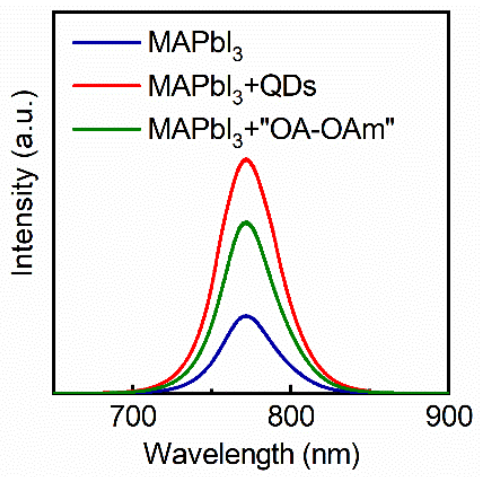

Figure S46. PL spectra of $\mathrm{P} 3 \mathrm{HT}$ on bare $\mathrm{MAPbI}_{3}$ and $\mathrm{MAPbI}_{3}$ with "OA-OAm" washed from QDs, and the one with QD interlayer.

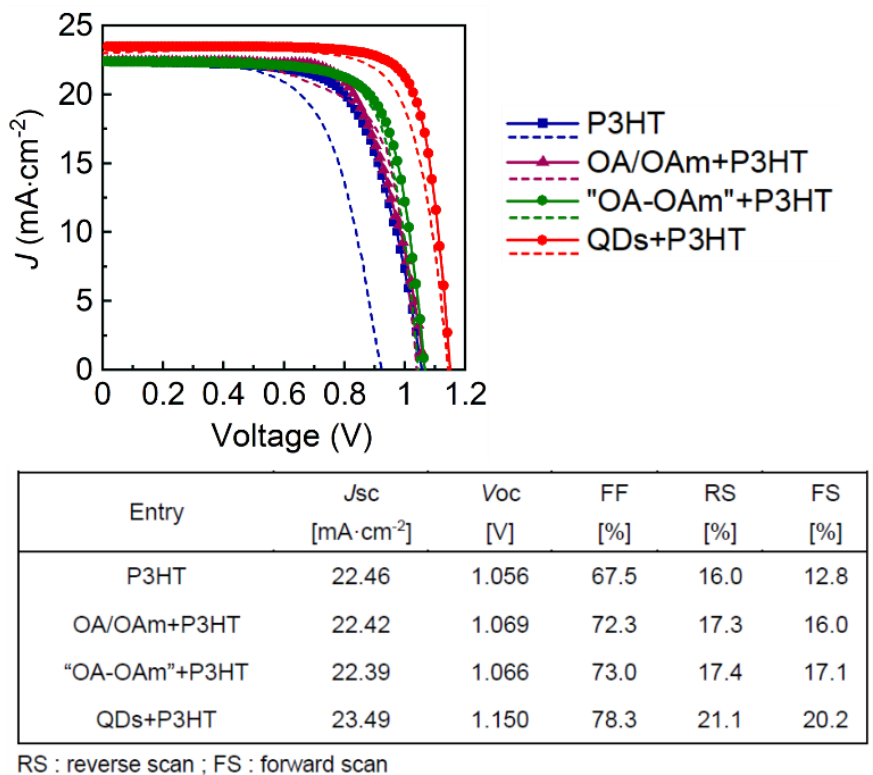

Figure S47. $J-V$ curves of dopant-free P3HT-based device with OA/OAm (octane solution at optimized concentration of $1 \mathrm{mg} / \mathrm{mL}$ ) as interlayer and the device with "OA-OAm" (ligands washed from QDs as interlayer). 
Functions of ligands: As shown in Raman spectra (Figure S45a), the regularity of P3HT were increased with the addition of ligands, similar with the trend of QD interlayers. The regulation effect on P3HT was supposed to result from Van der Waals interaction and hydrophobic interaction between alkyl chain of ligands on QDs and P3HT, to form possible molecular arrays. ${ }^{\mathrm{S} 6-8}$ In order to compare the functions of ligands ("OA-OAm" washed from QDs) and QD interlayers, hole mobility of $\mathrm{P} 3 \mathrm{HT}$ on ligand-covered $\mathrm{MAPbI}_{3}$ film was also tested and calculated. The mobility of $\mathrm{P} 3 \mathrm{HT}$ on ligand-covered $\mathrm{MAPbI}_{3}$ film showed a three-fold improvement compared to the one on bare $\mathrm{MAPbI}_{3}$ film, but the enhancement was not comparable to the case with QD interlayers (five-fold; Figure S45b). Besides the regulation function of ligands on P3HT, addition of ligands ("OA-OAm" washed from QDs) on $\mathrm{MAPbI}_{3}$ resulted in stronger PL emission (Figure S46), indicating that ligands formed a buffer layer on $\mathrm{MAPbI}_{3}$. To be noticed, since QDs were capped by OA and OAm as ligands, the functions of direct addition of OA and OAm were also studied. Figure S47 showed dopant-free P3HT-based devices with OA/OAm or with ligands washed from QDs ("OA-OAm"). These two cases both showed a slight increase in device efficiency with moderate enhancement in FF but inconspicuous increment in $V_{\mathrm{OC}}$ and $J_{\mathrm{SC}}$, indicating that ligands themselves played a similar but limited role in dopant-free HTL-based devices, which was not comparative with QD interlayers.

a

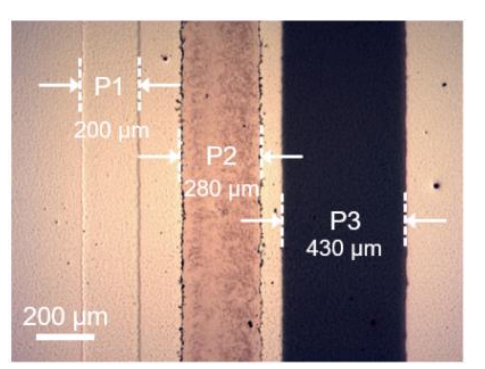

b

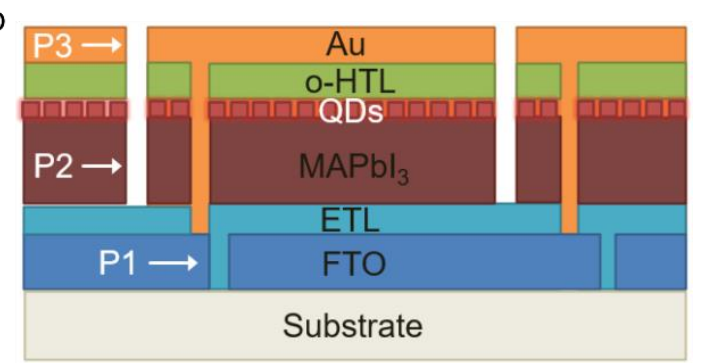

Figure S48. (a) Optical microscope image of P1, P2 and P3 lines of a fabricated module. (b) Schematic diagram of a cross-section view for the module structure.

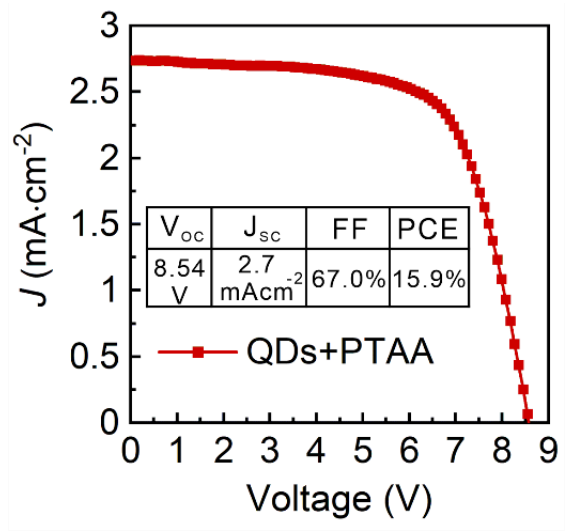

Figure S49. $J-V$ curve of a dopant-free PTAA-based PSC module with QD interlayer at an active area of $18.0 \mathrm{~cm}^{2}$. 


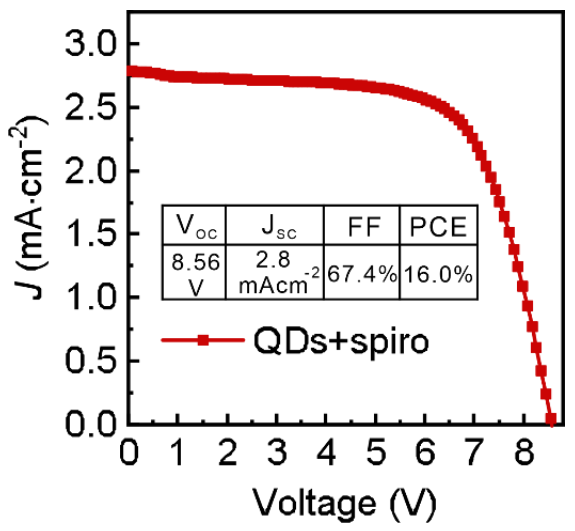

Figure S50. $J-V$ curve of a dopant-free spiro-based PSC module with QD interlayer at an active area of $18.0 \mathrm{~cm}^{2}$.

Table S1. Photovoltaic parameters of PSCs with dopant-free o-HTL single-layer, with QD and dopant-free o-HTL bilayers, or with lithium-doped o-HTL single-layer.

\begin{tabular}{lccccc}
\hline Entry & $J_{s c}\left[\mathrm{~mA} \cdot \mathrm{cm}^{-2}\right]$ & $V_{o c}[\mathrm{~V}]$ & FF $[\%]$ & Reverse scan [\%] & Forward scan [\%] \\
\hline P3HT & 22.46 & 1.056 & 67.5 & 16.0 & 12.8 \\
QDs+P3HT & 23.49 & 1.150 & 78.3 & 21.1 & 20.2 \\
P3HT/Li+/tBP & 22.88 & 1.074 & 71.7 & 17.6 & 16.7 \\
PTAA & 22.32 & 1.051 & 66.1 & 15.5 & 7.6 \\
QDs+PTAA & 22.70 & 1.118 & 75.8 & 19.2 & 19.3 \\
PTAA/Li $/$ tBP & 22.24 & 1.099 & 74.5 & 19.4 & 17.8 \\
spiro & 21.82 & 1.038 & 54.6 & 12.4 & 9.9 \\
QDs+spiro & 22.97 & 1.122 & 77.1 & 19.9 & 19.4 \\
spiro/Li+/tBP & 22.70 & 1.102 & 76.1 & 19.1 & 18.9 \\
\hline
\end{tabular}

Table S2. Photovoltaic parameters of P3HT-based devices without or with dopants.

Dopant-free P3HT

\begin{tabular}{|c|c|c|c|c|c|c|c|}
\hline \multirow[b]{2}{*}{ Device structure } & \multirow[b]{2}{*}{ HTM } & $V_{\mathrm{OC}}$ & $J_{\mathrm{SC}}$ & FF & PCE & \multirow[b]{2}{*}{ Year } & \multirow[b]{2}{*}{ Reference } \\
\hline & & {$[\mathrm{V}]$} & {$\left[\mathrm{mA} \cdot \mathrm{cm}^{-2}\right]$} & {$[\%]$} & {$[\%]$} & & \\
\hline \multirow{2}{*}{$\mathrm{FTO} / \mathrm{TiO}_{2} / \mathrm{MAPbI}_{2} \mathrm{Br} / \mathrm{HTM} / \mathrm{Au}$} & Spiro-OMeTAD/Li & 0.85 & 11.76 & 57.4 & 5.73 & \multirow[b]{2}{*}{2015} & \multirow[b]{2}{*}{ S9 } \\
\hline & P3HT & 0.82 & 12.93 & 62.8 & 6.64 & & \\
\hline \multirow{2}{*}{$\mathrm{FTO} / \mathrm{TiO}_{2} / \mathrm{MAPbI}_{2} \mathrm{Br} / \mathrm{P} 3 \mathrm{HT} / \mathrm{Au}$} & SC-PVK & 0.78 & 10.00 & 61.4 & 4.8 & \multirow[b]{2}{*}{2015} & \multirow[b]{2}{*}{$\mathrm{S} 10$} \\
\hline & BD-PVK & 0.95 & 15.45 & 69.3 & 10.2 & & \\
\hline \multirow{2}{*}{$\mathrm{FTO} / \mathrm{TiO}_{2} / \mathrm{MAPbI}_{3} / \mathrm{HTM} / \mathrm{Au}$} & Spiro-OMeTAD/Li & 1.07 & 24.3 & 73.6 & 19.1 & \multirow[b]{2}{*}{2017} & \multirow[b]{2}{*}{ S11 } \\
\hline & P3HT & 0.87 & 19.6 & 65.1 & 11.0 & & \\
\hline \multirow{2}{*}{ 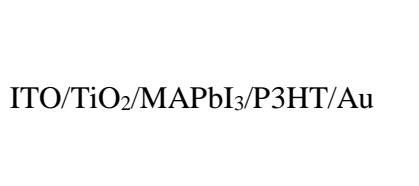 } & P3HT-44kDa & $\begin{array}{c}0.95 \\
\pm 0.019\end{array}$ & $\begin{array}{l}10.74 \\
\pm 0.69\end{array}$ & $\begin{array}{l}48.0 \\
\pm 1.9\end{array}$ & $\begin{array}{c}4.92 \\
\pm 0.60\end{array}$ & \multirow[b]{2}{*}{2017} & \multirow[b]{2}{*}{$\mathrm{S} 12$} \\
\hline & P3HT-124kDa & $\begin{array}{c}1.02 \\
\pm 0.009\end{array}$ & $\begin{array}{l}23.19 \\
\pm 1.20\end{array}$ & $\begin{array}{l}68.6 \\
\pm 6.5\end{array}$ & $\begin{array}{l}16.27 \\
\pm 1.48\end{array}$ & & \\
\hline
\end{tabular}




\begin{tabular}{|c|c|c|c|c|c|c|c|}
\hline \multirow{2}{*}{$\begin{array}{l}\text { ITO/ETM/ FA }{ }_{x} \mathrm{MA}_{1-\mathrm{x}} \mathrm{Pb} \\
\left(\mathrm{I}_{\mathrm{x}} \mathrm{Br}{ }_{1-\mathrm{x}}\right)_{3} / \mathrm{P} 3 \mathrm{HT} / \mathrm{MoO}_{3} / \mathrm{Ag}\end{array}$} & $\mathrm{TiO}_{2}$ & 1.03 & 20.23 & 59.2 & 12.78 & \multirow[b]{2}{*}{2019} & \multirow[b]{2}{*}{$\mathrm{S} 13$} \\
\hline & TCI-PDI & 1.07 & 18.16 & 76.8 & 14.73 & & \\
\hline \multirow{2}{*}{$\begin{array}{l}\mathrm{FTO} / \mathrm{TiO}_{2} / \mathrm{FA}_{\mathrm{x}} \mathrm{MA}_{1-\mathrm{x}} \mathrm{Pb} \\
\left(\mathrm{I}_{\mathrm{x}} \mathrm{Br}_{1-\mathrm{x}}\right)_{3} / \mathrm{P} 3 \mathrm{HT} / \mathrm{Au}\end{array}$} & P3HT & 0.93 & 24.79 & 69.0 & 15.8 & \multirow[b]{2}{*}{2019} & \multirow[b]{2}{*}{ S14 } \\
\hline & DHA/P3HT & 1.14 & 24.92 & 79.9 & 22.8 & & \\
\hline \multirow{2}{*}{$\mathrm{ITO} / \mathrm{SnO}_{2} / \mathrm{CsPbI}_{2} \mathrm{Br} / \mathrm{P} 3 \mathrm{HT} / \mathrm{Au}$} & P3HT & 1.17 & 15.24 & 78.7 & 14.08 & \multirow[b]{2}{*}{2020} & \multirow[b]{2}{*}{$\mathrm{S} 15$} \\
\hline & TFB/P3HT & 1.26 & 15.62 & 78.7 & 15.50 & & \\
\hline \multirow{2}{*}{$\begin{array}{l}\text { ITO/SnO } 2 /\left(\mathrm{FA}_{1-\mathrm{x}-\mathrm{y}} \mathrm{MA}_{\mathrm{x}} \mathrm{Cs}_{\mathrm{y}}\right) \\
\mathrm{Pb}\left(\mathrm{I}_{1-\mathrm{x}} \mathrm{Br}_{\mathrm{x}}\right)_{3} / \mathrm{P} 3 \mathrm{HT} / \mathrm{Au}\end{array}$} & P3HT & 0.90 & 23.09 & 63.1 & 13.13 & \multirow[b]{2}{*}{2020} & \multirow[b]{2}{*}{ S16 } \\
\hline & P3CT-BN/P3HT & 1.10 & 23.52 & 74.2 & 19.23 & & \\
\hline \multirow{2}{*}{$\begin{array}{l}\mathrm{FTO} / \mathrm{SnO}_{2} / 3 \mathrm{D}:(\mathrm{SIG}-2 \mathrm{D}) / \\
\mathrm{P} 3 \mathrm{HT} / \mathrm{Au}\end{array}$} & P3HT & 0.97 & 24.00 & 51.1 & 11.92 & \multirow{2}{*}{2021} & \multirow{2}{*}{ S17 } \\
\hline & SIG-2D/P3HT & 1.12 & 24.17 & 75.6 & 20.52 & & \\
\hline
\end{tabular}

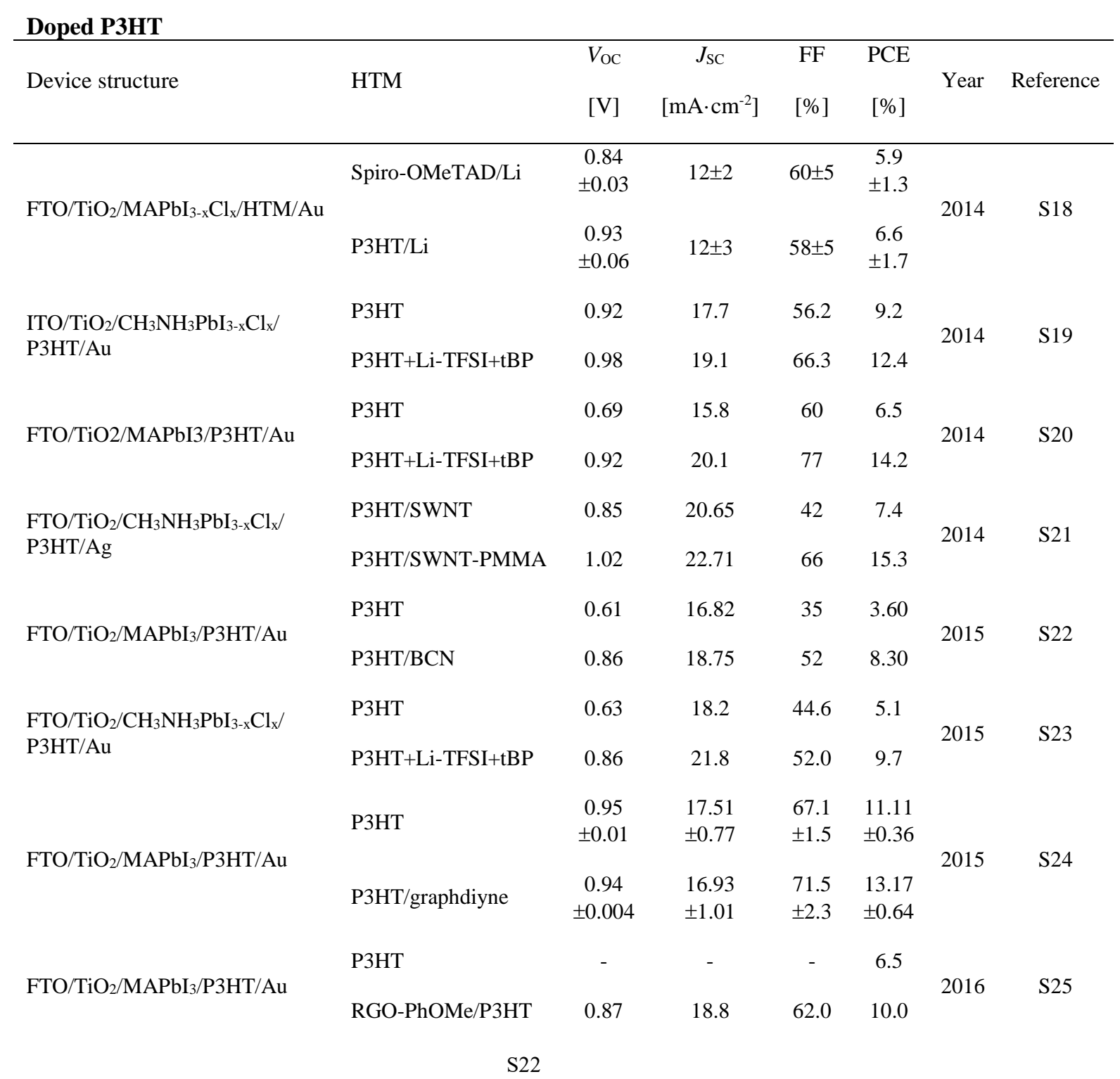




\begin{tabular}{|c|c|c|c|c|c|c|c|}
\hline \multirow{2}{*}{$\mathrm{FTO} / \mathrm{TiO}_{2} / \mathrm{MAPbI}_{3} / \mathrm{P} 3 \mathrm{HT} / \mathrm{Ag}$} & P3HT & 0.96 & 16.7 & 52.6 & 8.16 & \multirow{2}{*}{2016} & \multirow{2}{*}{ S26 } \\
\hline & P3HT+F-graphene & 0.99 & 19.7 & 70.6 & 13.82 & & \\
\hline \multirow{2}{*}{$\begin{array}{l}\mathrm{FTO} / \mathrm{TiO}_{2} /\left(\mathrm{FAPbI}_{3}\right)_{1-\mathrm{x}} \\
(\mathrm{MAPbBr})_{3} / \mathrm{P} 3 \mathrm{HT} / \mathrm{Au}\end{array}$} & P3HT & 0.96 & 19.5 & 55 & 10.3 & \multirow{2}{*}{2016} & \multirow{2}{*}{ S27 } \\
\hline & P3HT/F4TCNQ & 0.97 & 23.9 & 62 & 14.4 & & \\
\hline \multirow{2}{*}{ ITO/PCBM/MAPbI $3 / \mathrm{P3HT} / \mathrm{Ag}$} & LP-P3HT & 0.91 & 20.61 & 71.6 & 13.41 & \multirow{2}{*}{2016} & \multirow{2}{*}{ S28 } \\
\hline & LN-P3HT & 0.94 & 22.73 & 71.2 & 15.18 & & \\
\hline \multirow{2}{*}{$\mathrm{FTO} / \mathrm{TiO}_{2} / \mathrm{MAPbI}_{3} / \mathrm{P} 3 \mathrm{HT} / \mathrm{Au}$} & P3HT & 0.98 & 18.47 & 64.8 & 11.78 & \multirow{2}{*}{2016} & \multirow{2}{*}{ S29 } \\
\hline & $\mathrm{Pd} / \mathrm{P} 3 \mathrm{HT}$ & 1.01 & 22.16 & 69.1 & 15.40 & & \\
\hline \multirow{2}{*}{$\mathrm{ITO} / \mathrm{TiO}_{2} / \mathrm{MAPbI}_{3-\mathrm{x}} \mathrm{Cl}_{\mathrm{x}} / \mathrm{HTM} / \mathrm{Au}$} & P3HT & 0.94 & 20.50 & 56 & 10.8 & \multirow{2}{*}{2017} & \multirow{2}{*}{ S30 } \\
\hline & РТB7 & 0.98 & 22.94 & 70 & 15.9 & & \\
\hline \multirow[b]{2}{*}{ ITO/PCBM/MAPbI $3 / \mathrm{P3HT} / \mathrm{Au}$} & P3HT & 0.87 & 15.04 & 47.7 & 6.23 & \multirow[b]{2}{*}{2017} & \multirow[b]{2}{*}{ S31 } \\
\hline & Co-TFSI/P3HT & 1.06 & 21.83 & 70.3 & 16.28 & & \\
\hline \multirow{2}{*}{ FTO/ZnO/MAPbI/3TM/Ag } & P3HT & 0.86 & 11.67 & 59.0 & 5.92 & \multirow{2}{*}{2018} & \multirow{2}{*}{ S32 } \\
\hline & P3TAA/P3HT & 0.95 & 15.68 & 67.0 & 9.98 & & \\
\hline \multirow{2}{*}{$\mathrm{ITO} / \mathrm{TiO}_{2} / \mathrm{CsPbI}_{2} \mathrm{Br} / \mathrm{P} 3 \mathrm{HT} / \mathrm{Au}$} & RT-P3HT & 1.25 & 12.22 & 58.4 & 8.92 & \multirow{2}{*}{2018} & \multirow{2}{*}{ S33 } \\
\hline & Annealed-P3HT & 1.30 & 13.13 & 70.4 & 12.02 & & \\
\hline \multirow{2}{*}{$\mathrm{FTO} / \mathrm{TiO}_{2} / \mathrm{MAPbI}_{3} / \mathrm{P} 3 \mathrm{HT} / \mathrm{Au}$} & P3HT & 0.90 & 18.11 & 68.6 & 11.2 & \multirow{2}{*}{2018} & \multirow{2}{*}{ S34 } \\
\hline & $\mathrm{P} 3 \mathrm{HT}+\mathrm{Li}-\mathrm{TFSI}+\mathrm{tBP}$ & 0.91 & 18.36 & 79.7 & 13.4 & & \\
\hline \multirow{2}{*}{$\begin{array}{l}\mathrm{FTO} / \mathrm{TiO}_{2} / \mathrm{FA}_{x} \mathrm{MA}_{1-\mathrm{x}} \mathrm{Pb} \\
\left(\mathrm{I}_{\mathrm{x}} \mathrm{Br}_{1-\mathrm{x}}\right)_{3} / \mathrm{P} 3 \mathrm{HT} / \mathrm{Au}\end{array}$} & P3HT & 1.02 & 20.56 & 67.9 & 14.30 & \multirow{2}{*}{2018} & \multirow{2}{*}{ S35 } \\
\hline & $\mathrm{P} 3 \mathrm{HT}+\mathrm{Li}-\mathrm{TFSI}+\mathrm{tBP}$ & 1.07 & 21.20 & 77.2 & 17.55 & & \\
\hline $\mathrm{FTO} / \mathrm{TiO}_{2} / \mathrm{MAPbI}_{3-\mathrm{x}} \mathrm{Cl}_{\mathrm{x}} /$ & P3HT & 0.48 & 17.4 & 60 & 5.1 & 2010 & $\mathrm{~S} 36$ \\
\hline P3HT/Au & P3HT-MoS 2 & 0.53 & 21.3 & 64 & 7.2 & & \\
\hline & P3HT & 0.90 & 16.72 & 58.0 & 8.76 & & ת \\
\hline $\mathrm{FTO} / \mathrm{TiO}_{2} / \mathrm{MAPbI} / \mathrm{P} 3 \mathrm{HT} / \mathrm{Au}$ & P3HT:m-MTDATA & 0.94 & 17.34 & 58.7 & 9.53 & 2019 & S37 \\
\hline & P3HT & 1.54 & 7.27 & 76.1 & 8.50 & & \\
\hline $\mathrm{FTO} / \mathrm{TiO}_{2} / \mathrm{CsPbBr}_{3} / \mathrm{P} 3 \mathrm{HT} /$ carbon & $\mathrm{P} 3 \mathrm{HT} / \mathrm{ZnPc}$ & 1.58 & 7.65 & 83.1 & 10.03 & 2019 & S38 \\
\hline $\mathrm{FTO} / \mathrm{TiO}_{2} / \mathrm{CsPbI}_{2} \mathrm{Br} /$ & P3HT & 1.15 & 12.17 & 55.0 & 7.69 & 2010 & $\mathrm{~S} 30$ \\
\hline P3HT/carbon & P3HT-MWCNT & 1.21 & 13.35 & 62.0 & 10.01 & 2019 & 539 \\
\hline & $\mathrm{CsPbI}_{2} \mathrm{Br}$ & 1.08 & 14.21 & 55.89 & 8.56 & & \\
\hline & $\mathrm{CsPbI}_{2} \mathrm{Br}-\mathrm{Pb}(\mathrm{SCN})_{2}$ & 1.14 & 16.07 & 66.75 & 12.22 & 2019 & 340 \\
\hline $\mathrm{FTO} / \mathrm{TiO}_{2} / \mathrm{CsPbI}_{2} \mathrm{Br} / \mathrm{P} 3 \mathrm{HT} / \mathrm{Au}$ & P3HT & 1.14 & 13.23 & 80.35 & 12.12 & 2019 & S41 \\
\hline
\end{tabular}




\begin{tabular}{|c|c|c|c|c|c|c|c|}
\hline & P3HT-wash & 1.24 & 14.20 & 81.52 & 14.35 & & \\
\hline \multirow{2}{*}{$\mathrm{FTO} / \mathrm{SnO}_{2} / \mathrm{MAPbI}_{3} / \mathrm{P} 3 \mathrm{HT} / \mathrm{Au}$} & P3HT & 0.976 & 18.48 & 65.9 & 11.89 & \multirow{2}{*}{2019} & \multirow{2}{*}{ S42 } \\
\hline & $\mathrm{P} 3 \mathrm{HT} / \mathrm{N}-\mathrm{CuMe}_{2} \mathrm{Pc}$ & 1.008 & 22.44 & 73.4 & 16.61 & & \\
\hline \multirow{2}{*}{$\begin{array}{l}\mathrm{FTO} / \mathrm{ETL} / \mathrm{FA}_{\times} \mathrm{MA}_{1-\mathrm{P}} \mathrm{PbI}_{3} / \\
\mathrm{P} 3 \mathrm{HT} / \text { carbon }\end{array}$} & P3HT & $\begin{array}{c}0.99 \\
\pm 0.04\end{array}$ & $\begin{array}{l}19.33 \\
\pm 0.61\end{array}$ & $51 \pm 4$ & $\begin{array}{l}9.73 \\
\pm 0.95\end{array}$ & \multirow{2}{*}{2019} & \multirow{2}{*}{ S43 } \\
\hline & P3HT/graphene & $\begin{array}{c}1.06 \\
\pm 0.02\end{array}$ & $\begin{array}{l}22.30 \\
\pm 0.62\end{array}$ & $74 \pm 2$ & $\begin{array}{r}17.49 \\
\pm 0.42\end{array}$ & & \\
\hline \multirow{2}{*}{$\begin{array}{l}\mathrm{FTO} / \mathrm{mp}_{-} \mathrm{TiO}_{2} /\left(\mathrm{FA}_{1-\mathrm{x}-\mathrm{y}} \mathrm{MA}_{\mathrm{x}} \mathrm{Cs}_{\mathrm{y}}\right) \\
\mathrm{Pb}\left(\mathrm{I}_{1-\mathrm{x}} \mathrm{Br}_{\mathrm{x}}\right)_{3} / \mathrm{P} 3 \mathrm{HT} / \mathrm{Au}\end{array}$} & P3HT & 1.04 & 22.0 & 72.0 & 15.62 & \multirow{2}{*}{2019} & \multirow{2}{*}{ S44 } \\
\hline & $\mathrm{P} 3 \mathrm{HT} / \mathrm{Li} / \mathrm{tBP} / \mathrm{Co}$ & 1.09 & 23.86 & 73.7 & 19.25 & & \\
\hline \multirow{2}{*}{$\begin{array}{l}\mathrm{ITO} / \mathrm{SnO}_{2} /\left(\mathrm{FAPbI}_{3}\right)_{\mathrm{x}} \\
(\mathrm{CsPbBr} 3)_{1-\mathrm{x}} / \mathrm{P} 3 \mathrm{HT} / \mathrm{Au}\end{array}$} & P3HT/F4TCNQ/DCB & 0.87 & 20.20 & 56.5 & 9.94 & \multirow{2}{*}{2020} & \multirow{2}{*}{ S45 } \\
\hline & $\mathrm{P} 3 \mathrm{HT} / \mathrm{F} 4 \mathrm{TCNQ} / \mathrm{THF}$ & 0.92 & 22.22 & 66.2 & 13.54 & & \\
\hline \multirow{2}{*}{$\begin{array}{l}\mathrm{FTO} / \mathrm{TiO}_{2} / \mathrm{MAPbI}_{\mathrm{x}} \mathrm{Cl}_{3-\mathrm{x}} / \\
\mathrm{P} 3 \mathrm{HT} / \mathrm{Au}\end{array}$} & P3HT & 0.79 & 20.86 & 57.0 & 9.35 & \multirow{2}{*}{2020} & \multirow{2}{*}{ S46 } \\
\hline & $\mathrm{CNT}$ in $\mathrm{TiO}_{2}+\mathrm{P} 3 \mathrm{HT}$ & 0.86 & 23.52 & 71.0 & 14.37 & & \\
\hline \multirow{2}{*}{$\begin{array}{l}\mathrm{FTO} / \mathrm{SnO}_{2} / \mathrm{Cs}_{\mathrm{y}}\left(\mathrm{FA}_{\mathrm{x}} \mathrm{MA}_{1-\mathrm{x}}\right)_{1-\mathrm{y}} \\
\mathrm{Pb}\left(\mathrm{I}_{\mathrm{x}} \mathrm{Br} \mathrm{r}_{1-\mathrm{x}}\right)_{3} / \mathrm{P} 3 \mathrm{HT} / \mathrm{Au}\end{array}$} & P3HT & 1.00 & 21.98 & 59.8 & 13.40 & \multirow{2}{*}{2020} & \multirow{2}{*}{ S47 } \\
\hline & P3HT/AuNR & 1.03 & 24.34 & 71.8 & 16.88 & & \\
\hline \multirow[b]{2}{*}{$\begin{array}{l}\mathrm{FTO} / \mathrm{TiO}_{2} / \\
\mathrm{Cs}_{1-\mathrm{x}} \mathrm{Rb}_{\mathrm{P}} \mathrm{PbI}{ }_{2} \mathrm{Br} / \mathrm{P} 3 \mathrm{HT} / \mathrm{Au}\end{array}$} & $\mathrm{CsPbI}_{2} \mathrm{Br}$ & 1.29 & 14.98 & 75.0 & 14.48 & \multirow[b]{2}{*}{2020} & \multirow[b]{2}{*}{ S48 } \\
\hline & $\mathrm{Cs}_{0.99} \mathrm{Rb}_{0.01} \mathrm{PbI}_{2} \mathrm{Br}$ & 1.32 & 16.25 & 80.0 & 17.16 & & \\
\hline \multirow{2}{*}{$\begin{array}{l}\text { ITO/c-TiO2/PMMA:PCBM/ } \\
\text { Cso.05FA }_{0.88 M A_{0.07} \mathrm{PbI}_{2.56} \mathrm{Br}_{0.44} /} \\
\text { PMMA/P3HT:CuPc/Au }\end{array}$} & A-planar & - & $\begin{array}{l}21.73 \\
\pm 0.19\end{array}$ & $\begin{array}{l}0.741 \\
\pm 0.01\end{array}$ & $\begin{array}{l}19.64 \\
\pm 0.55\end{array}$ & \multirow{2}{*}{2021} & \multirow{2}{*}{ S49 } \\
\hline & Nano-patterned & $\begin{array}{c}1.217 \\
\pm 0.015\end{array}$ & $\begin{array}{l}21.85 \\
\pm 0.17\end{array}$ & $\begin{array}{l}0.824 \\
\pm 0.01\end{array}$ & $\begin{array}{l}21.91 \\
\pm 0.57\end{array}$ & & \\
\hline
\end{tabular}

Table S3. Photovoltaic parameters of dopant-free P3HT-based solar modules with or without QD interlayer (18.0- $\mathrm{cm}^{2}$ active area).

\begin{tabular}{lllll}
\hline Entry & $J_{s c}\left[\mathrm{~mA} \cdot \mathrm{cm}^{-2}\right]$ & $V_{o c}[\mathrm{~V}]$ & FF [\%] & PCE [\%] \\
\hline P3HT & 2.64 & 7.530 & 58.6 & 11.6 \\
QDs+P3HT & 2.79 & 8.842 & 71.4 & 17.6 \\
\hline
\end{tabular}

\section{References}

(S1) Chen, R.; Cao, J.; Duan, Y.; Hui, Y.; Chuong, T. T.; Ou, D.; Han, F.; Cheng, F.; Huang, X.; Wu, B.; Zheng, N. High-Efficiency, Hysteresis-Less, UV-Stable Perovskite Solar Cells with Cascade ZnO-ZnS Electron Transport Layer. J. Am. Chem. Soc. 2019, 141, 541-547.

(S2) Huang, X.; Chen, R.; Deng, G.; Han, F.; Ruan, P.; Cheng, F.; Yin, J.; Wu, B.; Zheng, N. Methylamine-DimerInduced Phase Transition toward MAPbI 3 Films and High-Efficiency Perovskite Solar Modules. J. Am. Chem. Soc. 2020, $142,6149-6157$. 
(S3) Hemasiri, N. H.; Kazim, S.; Ahmad, S. Reduced Trap Density and Mitigating the Interfacial Losses by Placing 2D Dichalcogenide Material at Perovskite/HTM Interface in a Dopant Free Perovskite Solar Cells. Nano Energy 2020, 77, 105292.

(S4) Jeon, N. J.; Lee, H. G.; Kim, Y. C.; Seo, J.; Noh, J. H.; Lee, J.; Seok, S. I. o-Methoxy Substituents in SpiroOMeTAD for Efficient Inorganic-Organic Hybrid Perovskite Solar Cells. J. Am. Chem. Soc. 2014, 136, 7837-7840.

(S5) Li, B.; Zhang, Y.; Zhang, L.; Yin, L. Graded Heterojunction Engineering for Hole-Conductor-Free Perovskite Solar Cells with High Hole Extraction Efficiency and Conductivity. Adv. Mater. 2017, 29, 1701221.

(S6) Mourdikoudis, S.; Liz-Marzán, L. M. Oleylamine in Nanoparticle Synthesis. Chem. Mater. 2013, 25, 1465-1476.

(S7) Wu, B.; Huang, H.; Yang, J.; Zheng, N.; Fu, G. Selective hydrogenation of alpha,beta-unsaturated aldehydes catalyzed by amine-capped platinum-cobalt nanocrystals. Angew. Chem. Int. Ed. 2012, 51, 3440-3443.

(S8) Wu, B.-H.; Yang, H.-Y.; Huang, H.-Q.; Chen, G.-X.; Zheng, N.-F. Solvent effect on the synthesis of monodisperse amine-capped Au nanoparticles. Chin. Chem. Lett. 2013, 24, 457-462.

(S9) Zhang, M.; Lyu, M.; Yu, H.; Yun, J. H.; Wang, Q.; Wang, L. Stable and Low-Cost Mesoscopic $\mathrm{CH}_{3} \mathrm{NH}_{3} \mathrm{PbI}_{2} \mathrm{Br}$ Perovskite Solar Cells by Using a Thin Poly(3-hexylthiophene) Layer as a Hole Transporter. Chem. Eur. J. 2015, 21, 434-439.

(S10) Zhang, M.; Yu, H.; Yun, J. H.; Lyu, M.; Wang, Q.; Wang, L. Facile Preparation of Smooth Perovskite Films for Efficient Meso/Planar Hybrid Structured Perovskite Solar Cells. Chem. Commun. 2015, 51, 10038-10041.

(S11) Jimenez-Lopez, J.; Cambarau, W.; Cabau, L.; Palomares, E. Charge Injection, Carriers Recombination and HOMO Energy Level Relationship in Perovskite Solar Cells. Sci Rep 2017, 7, 6101.

(S12) Nia, N. Y.; Matteocci, F.; Cina, L.; Di Carlo, A. High-Efficiency Perovskite Solar Cell Based on Poly(3Hexylthiophene): Influence of Molecular Weight and Mesoscopic Scaffold Layer. ChemSusChem 2017, 10, 3854-3860. (S13) Zou, D.; Yang, F.; Zhuang, Q.; Zhu, M.; Chen, Y.; You, G.; Lin, Z.; Zhen, H.; Ling, Q. Perylene Diimide-Based Electron-Transporting Material for Perovskite Solar Cells with Undoped Poly(3-hexylthiophene) as Hole-Transporting Material. ChemSusChem 2019, 12, 1155-1161.

(S14) Jung, E. H.; Jeon, N. J.; Park, E. Y.; Moon, C. S.; Shin, T. J.; Yang, T. Y.; Noh, J. H.; Seo, J. Efficient, Stable and Scalable Perovskite Solar Cells Using Poly(3-hexylthiophene). Nature 2019, 567, 511-515.

(S15) Li, M. H.; Liu, S. C.; Qiu, F. Z.; Zhang, Z. Y.; Xue, D. J.; Hu, J. S. High-Efficiency CsPbI ${ }_{2} B r$ Perovskite Solar Cells with Dopant-Free Poly(3-hexylthiophene) Hole Transporting Layers. Adv. Energy Mater. 2020, 10, 2000501.

(S16) Zhang, W.; Wan, L.; Fu, S.; Li, X.; Fang, J. Reducing Energy Loss and Stabilising the Perovskite/Poly (3hexylthiophene) Interface Through a Polyelectrolyte Interlayer. J. Mater. Chem. A 2020, 8, 6546-6554.

(S17) Jang, Y.-W.; Lee, S.; Yeom, K. M.; Jeong, K.; Choi, K.; Choi, M.; Noh, J. H. Intact 2D/3D Halide Junction Perovskite Solar Cells via Solid-Phase In-Plane Growth. Nat Energy 2021, DOI: 10.1038/s41560-020-00749-7.

(S18) Di Giacomo, F.; Razza, S.; Matteocci, F.; D'Epifanio, A.; Licoccia, S.; Brown, T. M.; Di Carlo, A. High Efficiency $\mathrm{CH} 3 \mathrm{NH} 3 \mathrm{PbI}_{(3-\mathrm{x})} \mathrm{Cl}_{\mathrm{x}}$ Perovskite Solar Cells with Poly(3-hexylthiophene) Hole Transport Layer. J. Power Sources 2014, 251, 152-156.

(S19) Guo, Y.; Liu, C.; Inoue, K.; Harano, K.; Tanaka, H.; Nakamura, E. Enhancement in the Efficiency of an OrganicInorganic Hybrid Solar Cell With a Doped P3HT Hole-Transporting Layer on a Void-Free Perovskite Active Layer. J. Mater. Chem. A 2014, 2, 13827-13830.

(S20) Heo, J. H.; Im, S. H. $\mathrm{CH}_{3} \mathrm{NH}_{3} \mathrm{PbI}_{3} /$ Poly-3-hexylthiophen Perovskite Mesoscopic Solar Cells: Performance Enhancement by Li-Assisted Hole Conduction. Phys. Status Solidi RRL 2014, 8, 816-821.

(S21) Habisreutinger, S. N.; Leijtens, T.; Eperon, G. E.; Stranks, S. D.; Nicholas, R. J.; Snaith, H. J. Carbon Nanotube/Polymer Composites as a Highly Stable Hole Collection Layer in Perovskite Solar Cells. Nano Lett. 2014, 14 , 5561-5568.

(S22) Cai, M.; Tiong, V. T.; Hreid, T.; Bell, J.; Wang, H. An Efficient Hole Transport Material Composite Based on Poly(3-hexylthiophene) and Bamboo-Structured Carbon Nanotubes for High Performance Perovskite Solar Cells. J. Mater. Chem. A 2015, 3, 2784-2793.

(S23) Bi, H.; Zhang, Y. Influence of the Additives in Poly(3-Hexylthiophene) Hole Transport Layer on the Performance of Perovskite Solar Cells. Mater. Lett. 2015, 161, 767-769.

(S24) Xiao, J.; Shi, J.; Liu, H.; Xu, Y.; Lv, S.; Luo, Y.; Li, D.; Meng, Q.; Li, Y. Efficient $\mathrm{CH}_{3} \mathrm{NH}_{3} \mathrm{PbI}_{3}$ Perovskite Solar Cells Based on Graphdiyne (GD)-Modified P3HT Hole-Transporting Material. Adv. Energy Mater. 2015, 5, 1401943.

(S25) Gatti, T.; Casaluci, S.; Prato, M.; Salerno, M.; Di Stasio, F.; Ansaldo, A.; Menna, E.; Di Carlo, A.; Bonaccorso, F. Boosting Perovskite Solar Cells Performance and Stability through Doping a Poly-3(hexylthiophene) Hole Transporting Material with Organic Functionalized Carbon Nanostructures. Adv. Funct. Mater. 2016, 26, $7443-7453$.

(S26) Ye, J.; Li, X.; Zhao, J.; Mei, X.; Li, Q. Efficient and Stable Perovskite Solar Cells Based on Functional GrapheneModified P3HT Hole-Transporting Layer. RSC Adv. 2016, 6, 36356-36361.

(S27) Zhang, Y.; Elawad, M.; Yu, Z.; Jiang, X.; Lai, J.; Sun, L. Enhanced Performance of Perovskite Solar Cells with P3HT Hole-Transporting Materials via Molecular p-Type Doping. RSC Adv. 2016, 6, 108888-108895.

(S28) Park, M.; Park, J.-S.; Han, I. K.; Oh, J. Y. High-Performance Flexible and Air-Stable Perovskite Solar Cells with a Large Active Area Based on Poly(3-hexylthiophene) Nanofibrils. J. Mater. Chem. A 2016, 4, 11307-11316.

(S29) Cao, J.; Mo, S.; Jing, X.; Yin, J.; Li, J.; Zheng, N. Trace Surface-Clean Palladium Nanosheets as a Conductivity Enhancer in Hole-Transporting Layers to Improve the Overall Performances of Perovskite Solar Cells. Nanoscale 2016, $8,3274-3277$. 
(S30) Ahmadi, M.; Hsiao, Y.-C.; Wu, T.; Liu, Q.; Qin, W.; Hu, B. Effect of Photogenerated Dipoles in the Hole Transport Layer on Photovoltaic Performance of Organic-Inorganic Perovskite Solar Cells. Adv. Energy Mater. 2017, 7 , 1601575.

(S31) Jung, J. W.; Park, J.-S.; Han, I. K.; Lee, Y.; Park, C.; Kwon, W.; Park, M. Flexible and Highly Efficient Perovskite Solar Cells with a Large Active Area Incorporating Cobalt-Doped Poly(3-Hexylthiophene) for Enhanced Open-Circuit Voltage. J. Mater. Chem. A 2017, 5, 12158-12167.

(S32) Shit, A.; Chal, P.; Nandi, A. K. Copolymers of Poly(3-thiopheneacetic Acid) with Poly(3-hexylthiophene) as Hole-Transporting Material for Interfacially Engineered Perovskite Solar Cell by Modulating Band Positions for Higher Efficiency. Phys. Chem. Chem. Phys. 2018, 20, 15890-15900.

(S33) Zeng, Q.; Zhang, X.; Feng, X.; Lu, S.; Chen, Z.; Yong, X.; Redfern, S. A. T.; Wei, H.; Wang, H.; Shen, H.; Zhang, W.; Zheng, W.; Zhang, H.; Tse, J. S.; Yang, B. Polymer-Passivated Inorganic Cesium Lead Mixed-Halide Perovskites for Stable and Efficient Solar Cells with High Open-Circuit Voltage over 1.3 V. Adv. Mater. 2018, 30, 1705393.

(S34) Ulfa, M.; Zhu, T.; Goubard, F.; Pauporté, T. Molecular versus Polymeric Hole Transporting Materials for Perovskite Solar Cell Application. J. Mater. Chem. A 2018, 6, 13350-13358.

(S35) Zhou, P.; Bu, T.; Shi, S.; Li, L.; Zhang, Y.; Ku, Z.; Huang, F.; Peng, Y.; Zhong, J.; Cheng, Y.-B.; Huang, F. Efficient and Stable Mixed Perovskite Solar Cells Using P3HT as a Hole Transporting Layer. J. Mater. Chem. C. 2018, $6,5733$.

(S36) Ray, R.; Sarkar, A. S.; Pal, S. K. Improving Performance and Moisture Stability of Perovskite Solar Cells through Interface Engineering with Polymer-2D MoS 2 Nanohybrid. Sol. Energy 2019, 193, 95-101.

(S37) Kim, J. Y.; Kwak, G.; Choi, Y. C.; Kim, D.-H.; Han, Y. S. Enhanced Performance of Perovskite Solar Cells by Incorporation of a Triphenylamine Derivative into Hole-Transporting Poly(3-hexylthiophene) Layers. J. Ind. Eng. Chem. 2019, 73, 175-181.

(S38) Liu, Y.; He, B.; Duan, J.; Zhao, Y.; Ding, Y.; Tang, M.; Chen, H.; Tang, Q. Poly(3-hexylthiophene)/Zinc Phthalocyanine Composites for Advanced Interface Engineering of 10.03\%-Efficiency CsPbBr3 Perovskite Solar Cells. J. Mater. Chem. A 2019, 7, 12635-12644.

(S39) Wang, G.; Liu, J.; Chen, K.; Pathak, R.; Gurung, A.; Qiao, Q. High-Performance Carbon Electrode-Based $\mathrm{CsPbI}_{2} \mathrm{Br}$ Inorganic Perovskite Solar Cell Based on Poly(3-hexylthiophene)-Carbon Nanotubes Composite HoleTransporting Layer. J. Colloid Interface Sci. 2019, 555, 180-186.

(S40) Ye, Z.; Zhou, J.; Hou, J.; Deng, F.; Zheng, Y.-Z.; Tao, X. Low Temperature-Processed Stable and Efficient Carbon-Based $\mathrm{CsPbI}_{2} \mathrm{Br}$ Planar Perovskite Solar Cells by In Situ Passivating Grain Boundary and Trap Density. Sol. RRL 2019, 3, 1900109.

(S41) Heo, J. H.; Kim, D. H.; Park, J. K.; Choi, Y. K.; Lee, D. S.; Im, S. H. Thermally Stable Inorganic CsPbI ${ }_{2} B r$ Mesoscopic Metal Halide Perovskite Solar Submodules. ACS Appl. Mater. Inter. 2019, 11, 43066-43074.

(S42) Hu, Q.; Rezaee, E.; Dong, Q.; Shan, H.; Chen, Q.; Wang, L.; Liu, B.; Pan, J.-H.; Xu, Z.-X. P3HT/Phthalocyanine Nanocomposites as Efficient Hole-Transporting Materials for Perovskite Solar Cells. Sol. RRL 2019, 3, 1800264.

(S43) Chu, Q.-Q.; Ding, B.; Peng, J.; Shen, H.; Li, X.; Liu, Y.; Li, C.-X.; Li, C.-J.; Yang, G.-J.; White, T. P.; Catchpole, K. R. Highly Stable Carbon-Based Perovskite Solar Cell with a Record Efficiency of over 18\% via Hole Transport Engineering. J. Mater. Sci. Technol. 2019, 35, 987-993.

(S44) Yaghoobi Nia, N.; Lamanna, E.; Zendehdel, M.; Palma, A. L.; Zurlo, F.; Castriotta, L. A.; Di Carlo, A. Doping Strategy for Efficient and Stable Triple Cation Hybrid Perovskite Solar Cells and Module Based on Poly(3hexylthiophene) Hole Transport Layer. Small 2019, 15, e1904399.

(S45) Tran, H.-C. V.; Jiang, W.; Lyu, M.; Chae, H. Tetrahydrofuran as Solvent for P3HT/F4-TCNQ Hole-Transporting Layer to Increase the Efficiency and Stability of FAPbI 3 -Based Perovskite Solar Cell. J. Phys. Chem. C 2020, 124, 1409914104.

(S46) Siva, U.; Murugathas, T.; Yohi, S.; Natarajan, M.; Velauthapillai, D.; Ravirajan, P. Single Walled Carbon Nanotube Incorporated Titanium Dioxide and Poly(3-Hexylthiophene) as Electron and Hole Transport Materials for Perovskite Solar Cells. Mater. Lett. 2020, 276, 128174.

(S47) Wang, J.; Hu, Q.; Li, M.; Shan, H.; Feng, Y.; Xu, Z.-X. Poly(3-hexylthiophene)/Gold Nanorod Composites as Efficient Hole-Transporting Materials for Perovskite Solar Cells. Sol. RRL 2020, 4, 2000109.

(S48) Patil, J. V.; Mali, S. S.; Hong, C. K. A-Site Rubidium Cation-Incorporated CsPbI ${ }_{2} B r$ All-Inorganic Perovskite Solar Cells Exceeding 17\% Efficiency. Sol. RRL 2020, 4, 2000164.

(S49) Peng, J.; Walter, D.; Ren, Y.; Tebyetekerwa, M.; Wu, Y.; Duong, T.; Lin, Q.; Li, J.; Lu, T.; Mahmud, M. A.; Lem, O. L. C.; Zhao, S.; Liu, W.; Liu, Y.; Shen, H.; Li, L.; Kremer, F.; Nguyen, H. T.; Choi, D.-Y.; Weber, K. J.; Catchpole, K. R.; White, T. P. Nanoscale Localized Contacts for High Fill Factors in Polymer-Passivated Perovskite Solar Cells. Science 2021, 371, 390-395. 